\title{
Phenotype variation in human immunodeficiency virus type 1 transmission and disease progression
}

\author{
Mariangela Cavarelli* and Gabriella Scarlatti \\ Viral Evolution and Transmission Unit, Division of Immunology, Transplantation and Infectious Diseases, San \\ Raffaele Scientific Institute, Milan, Italy
}

\begin{abstract}
Human immunodeficiency virus type I (HIV-1) infects target cells through interaction with the CD4 molecule and chemokine receptors, mainly CCR5 and CXCR4. Viral isolates can be phenotypically classified based on the co-receptor they utilize to infect target cells. Thus, R5 and X4 virus use respectively CCR5 and CXCR4, whereas R5X4 virus can use either CCR5 or CXCR4. This review describes the central role played by co-receptor expression and usage for HIV-1 cell tropism, transmission and pathogenesis. We discuss various hypotheses proposed to explain the preferential transmission of R5 viruses and the mechanisms driving the change of HIV-1 co-receptor usage in the course of infection. Recent insights in the intrinsic variability of R5 viruses and their role in influencing disease progression in both adults and children are also discussed.
\end{abstract}

Keywords: HIV-1, co-receptor usage, tropism, transmission, disease progression

\section{Introduction}

Human immunodeficiency virus type 1 (HIV-1) entry into the host cell is dependent upon binding of the virus envelope protein (env) to the cellular receptor CD4 and a co-receptor, generally the chemokine receptors CCR5 or CXCR4. The identification of chemokine receptors as the co-receptors of HIV-1 improved our understanding of the pathogenesis of HIV-1 infection with respect to the mechanism of viral entry, viral tropism and differences in disease course among infected individuals. CCR5 is the predominant co-receptor exploited for transmission and replication in vivo, and R5 viruses are detected at all stages of infection. CXCR4-using virus variants evolve in about one-half of subtype B infected individuals, and their emergence is associated with an accelerated course of the disease. Here we will

* Corresponding author: Mariangela Cavarelli, $\mathrm{PhD}$, Viral Evolution and Transmission, San Raffaele Scientific Institute, Via Olgettina 58, 20132 Milano, Italy. Tel.: +39 022643 4907; Fax: +39 022643 4905; E-mail: cavarelli.mariangela@hsr.it. discuss the chemokine receptor used by HIV-1 to infect target cells, their relevance to define viral tropism, their involvement in viral transmission, viral phenotypic evolution and disease progression both in adult and paediatric HIV-1 infected patients.

\section{Identification of CCR5 and CXCR4 as HIV-1 co-receptors: The history}

Almost immediately after the discovery of HIV-1 as the causative agent of HIV/AIDS, the CD4 molecule was identified as the main receptor used by the virus to infect target cells. Early evidence derived from the observation that infection was inhibited with monoclonal antibodies to CD4 [1]. This finding was later confirmed demonstrating that resistant human cells transfected with a recombinant copy of the CD4 gene became susceptible to HIV-1 infection [2,3]. Soon thereafter evidences started to accumulate indicating that CD4 alone was not sufficient to explain HIV-1 tropism for different target cells in vitro. Two main observations supported 
the notion that a co-receptor was required for HIV-1 entry. The first one was that CD4-transduced human cells were permissive for HIV-1 infection and replication, but transfected murine cells were not, despite appropriate processing and delivery of CD4 to the cell surface $[4,5]$. The second evidence came from experiments with murine/human cell hybrids that supported the conclusion that HIV-1 required a positive cofactor (co-receptor) specific for human cells for productive infection [6].

Additional evidences that a co-receptor for HIV-1 entry was required, derived from the observation that HIV1 exhibited in vitro distinct cellular tropism for CD4+ human target cells, CD4+ T cells and macrophages, which brought to a first attempt of classification of HIV1 as T cell line tropic (TCL-tropic) and Macrophagetropic (M-tropic).

In 1995, the discovery that the chemokines RANTES (regulated on activation, normal $\mathrm{T}$ cell expressed and secreted), MIP- $1 \alpha$ and MIP- $1 \beta$ (macrophage inflammatory protein) had a strong inhibitory effect on some viral strains changed radically the knowledge on viral entry [7]. Shortly thereafter Feng et al., using a novel cDNA cloning strategy based on the ability of a cDNA library to render a CD4-expressing murine cell permissive for fusion with cells expressing env from TCLtropic HIV strains, identified a new protein, defined "fusin" [8]. This protein is a member of the superfamily of the seven transmembrane domain $G$ protein-coupled receptors, and so a putative chemokine receptor, but no ligands or functional activity was found. These observations prompted several groups to investigate the possible involvement of other chemokine receptors in the entry of HIV into cells. On one hand it was soon demonstrated that fusin is indeed a chemokine receptor, specific for the CXC chemokine stromal cell derived factor-1 (SDF-1) $\alpha$ and $\beta$, and renamed CXCR4 [9, 10]. On the other hand the chemokine receptor for RANTES, MIP- $1 \alpha$ and MIP- $1 \beta$ was identified and designated CCR5 $[11,12]$. CXCR4 was shown to be the main receptor for TCL-tropic HIV strain and SDF-1 a selective inhibitor, and within one week five independent groups demonstrated that CCR5 was the main co-receptor for M-tropic strains [13-16].

These findings consequently fused the two formerly separate fields of HIV-1 and chemokine research and unveiled a fascinating new horizon for the understanding of HIV-1 pathogenesis. Presently a wide array of chemokine and chemokine-like receptors act as co-receptors for HIV-1 in vitro, including CCR2b, CCR3, STRL33/Bonzo, GPR1 and GPR15/BOB and
CX3CR1, to name but a few, however, current evidences suggests that co-receptors other than CCR5 and CXCR4 have limited use in vivo [17-23]. The factors that preclude the use of a wide range of coreceptors in vivo, as well as the reasons why the virus fails to evolve variants capable of exploiting alternative co-receptors, are not yet known.

\section{HIV-1 cellular tropism explained by co-receptor usage}

Before the identification of chemokine receptors as HIV-1 co-receptors, Asjo et al. described two distinct groups of viruses, defined as slow-low and rapid-high, depending on their replication rates in peripheral blood mononuclear cells (PBMCs) [24]. Further differences in tropism of the virus isolates emerged when CD4+ cells other than $\mathrm{T}$ cells were used as target. Some isolates grew well in T-cell lines, but showed poor or no infectivity for primary macrophages, and were defined T-cell line tropic (TCL-tropic). Other virus isolates showed the opposite preference, infecting primary macrophage much more efficiently than continuous T-cell lines, and were defined macrophage-tropic (M-tropic) [25]. The distinction was not always that sharp with isolates capable of infecting both cell targets, called dual-tropic. An important contribution came from the Dutch group which introduced a new definition of the two groups of viruses: syncytium-inducing (SI) or non syncytium-inducing (NSI) according to their capacity to induce cytopathic effect of the permissive T-cell line MT-2 [26]. The genetic determinants for the two types of viral phenotypes were localized in the gp120 env sequence and predominantly in the V3 loop (for a review see [27]).

The identification of CCR5 and CXCR4 as the main HIV-1 co-receptors explained the difference in cell tropism of the virus isolates as well as their sensitivity to the natural ligands of these receptors, the chemokines RANTES, MIP- $1 \alpha$ and MIP- $1 \beta$, or SDF-1, respectively. NSI variants use CCR5 (expressed by primary macrophages and primary $\mathrm{T}$ cells), while SI variants use CXCR4 (primarily expressed by continuous $\mathrm{T}$ cell lines and primary $\mathrm{T}$ cells) $[8,13-16,19]$. Thus, a new nomenclature has been proposed in 1998 [28]: viruses using CCR5 were designated R5, whereas those using only CXCR4 were nominated X4 or R5X4 when able to use either co-receptor (Fig. 1).

Recently, Karlsson et al. deeply explored the intrinsic variability of the replication capacity and the sensitivity 


\section{HIV-1 phenotype}

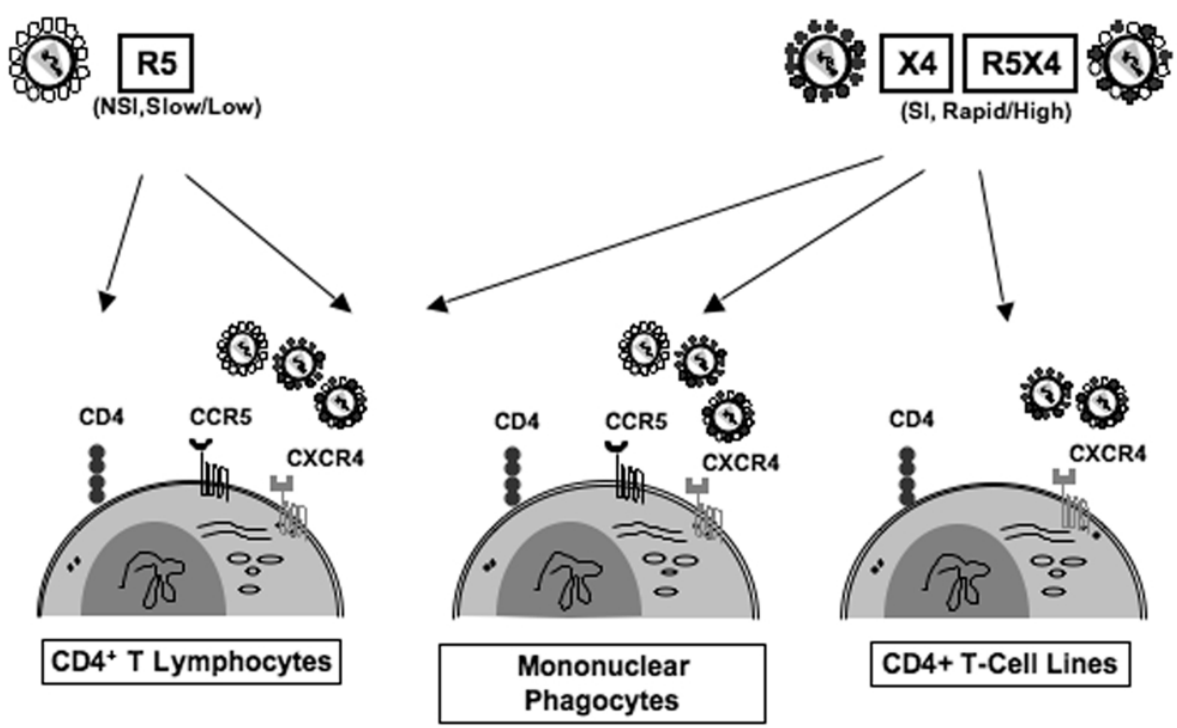

Fig. 1. HIV-1 tropism. R5 viruses replicate efficiently in primary CD4+ T lymphocytes and macrophages, but not in CD4+ T cell lines. X4 and R5X4 viruses replicate in primary CD4+ T lymphocytes, macrophages and CD4+ T cell lines.

to $\beta$-chemokines of R5 viruses. They infected a panel of U87.CD4 cells expressing a series of chimeric receptors between CCR5 and CXCR4 (called FC-1, FC-2 and FC-4b) with R5 viruses obtained from HIV-1 infected individuals throughout disease progression [29]. They were able to propose a more subtle classification of CCR5-using viruses according to their ability to use exclusively the wild type-CCR5 (named R5 ${ }^{\text {narrow) }}$, or also different combinations of the CCR5/CXCR4 chimeric receptors (named $\mathrm{R} 5^{\text {broad }}$ ). Depending on the number of chimeric receptor used, the $\mathrm{R} 5$ broad phenotype could be further divided into $\mathrm{R} 5^{\text {broad(1) }}, \mathrm{R} 5^{\text {broad(2) }}$ or R5 ${ }^{\text {broad(3). }}$.

\section{Co-receptor use and cell tropism are related but distinct Env's characteristics}

Although cellular tropism is generally explained by coreceptor usage, there are some exceptions that make the concept of tropism controversial. The coexpression of the CD4 molecule and selected coreceptors have identified monocytes, macrophages, microglia, dendritic cells (DC), Langerhans cells and lymphoid cells such as thymocytes and CD4+ T cells as potential target cells for HIV-1. However, the mere coexpression of the appropriate receptors does not warrant the capacity of a cell to support productive infection.
Primary human macrophages express CCR5 and at moderate levels CXCR4 [30-32], however a complex infectivity pattern has been observed. Indeed, most R5 isolates are able to infect macrophages [33-38]. However, HIV-1 isolates that use CCR5 but yet fail to replicate in macrophages exist $[39,40]$, suggesting a postentry inhibition of the replication. A better understanding of the viral and cellular factors, required for productive HIV-1 replication and infection, may facilitate the discovery of new and exploitable therapeutic avenues.

The capacity of $\mathrm{X} 4$ viruses to infect macrophages is a long lasting controversial issue. The differences observed between different studies could probably be ascribed to different preparation of the macrophages. However, macrophages can be resistant to infection with X4 isolates, despite the presence of CXCR4 on their surface $[41,42]$. The relatively low level of expression of the CD4 molecule on macrophages together with a higher CD4 dependency of X4 than R5 variants, may lead to a less efficient entry of X4 viruses into macrophages [43,44]. Evidence for this explanation comes from studies, in which over-expression of CD4 rendered macrophages more permissive to infection with primary $\mathrm{X} 4$ viruses $[45,46]$. Additional evidences suggest that primary X4 isolates $[47,48]$, as well as some R5X4 viruses [32,49,50] may infect different types of macrophages. 
It has also to be highlighted that additional factors may impact viral tropism, like receptor density, conformation heterogeneity, and post-translation modifications of the chemokines receptors (reviewed in [51]). All of them render the question of how HIV-1 env interacts with the co-receptors more complex than the mere definition of the co-receptor usage by any given viral strain. Indeed, it is known, that accessory genes can, at least in vitro, interfere with cell tropism. An example are $v p r, v p u$ and vif, accessory genes dispensable for infection and replication in $\mathrm{T}$ cell lines, which instead are required to various extend for infection of primary macrophages and PBMCs [52-54].

\section{Relevance of co-receptor usage in HIV-1 transmission and establishment of infection}

Viral co-receptor usage is known to play a critical role in transmission of HIV-1 infection. In vivo, R5 variants are preferentially transmitted, independently of the transmission route, in both adults and children [42,55-61]. X4 viruses are rarely recovered from newly infected individuals [58,62,63], also when such variants are present in the transmitting source. These results suggest that CCR5 usage plays an important role during viral transmission and initial dissemination in the host, and that some restriction to transmission of $\mathrm{X} 4$ viruses may exists.

The presence of R5 variants during early stages of HIV-1 infection suggests that macrophages may be one of the principal targets for the establishment of infection after transmission [60,61]. Analogously, DCs and Langerhans cells, abundant at mucosal sites, have also been implicated in transmission [64-68]. A study conducted with rhesus monkeys infected with simian immunodeficiency virus (SIV) via vaginal exposure, identified Langerhans cells as the first cellular target [69]. These cells capture the antigen at peripheral tissue level and transport it to lymphoid organs for presentation to $\mathrm{T}$ cells. The preferential expression of CCR5 on DCs could explain why the majority of transmission events are mediated by R5 viruses. Although there has been some initial controversy whether HIV-1 can productively infect DCs [70], it has been extensively demonstrated that the specific C type lectin DC-SIGN, expressed on immature DCs, allows capture of the virus and infection through a CCR5-dependent mechanism (cis infection). DCs can capture the virus also through DC-SIGN/gp120 interaction and efficiently transfer it to CD4+ T cells (trans infection), without becoming infected [71].

An alternative explanation for the predominance of $\mathrm{R} 5$ variants early in infection could be offered by the differential tropism of R5 and X4 variants for different lymphocyte subsets [72]. In vivo CCR5 is mainly expressed on activated memory $\mathrm{T}$ cells [73-75], while CXCR4 predominates on naïve and resting memory $\mathrm{T}$ cells [74]. DCs reaching the gut-associated lymphoid tissue (the main site of early HIV replication in both humans and macaques) induce activation of CD4+ $\mathrm{T}$ cells, which acquire a memory phenotype [76-79]. Indeed, in vivo and in vitro studies confirm that R5 isolates preferentially infect CCR5+ activated memory $\mathrm{T}$ cells, whereas $\mathrm{X} 4$ isolates infect $\mathrm{CXCR} 4+$ cells, which generally have a naïve or resting memory phenotype [73]. These resting cells may not provide the intracellular requirements for productive infection of $\mathrm{X} 4$ viruses [80-82].

An additional mechanism that may influence transmission at mucosal level is mediated by the coreceptor/chemokine system. Mucosal epithelial cells naturally secrete high levels of SDF-1 $\alpha$, the natural ligand of CXCR4 [83]. Consequently the restriction in transmission of $\mathrm{X} 4$ variants may arise from a combination of high level of HIV-1 inhibitory chemokine and a consequent down-regulation of CXCR4 on T-lymphocytes and macrophages in the tissues. This observation may provide an explanation for the restricted transmission of $\mathrm{X} 4$ viruses at mucosal level, but not for that via the parental route, which occurs despite similar levels of expression of the two co-receptors on cells in the peripheral blood [64,66,68,74,84,85].

The differential use of CCR 5 by R5 and R5X 4 viruses has also been proposed as a possible explanation for the infrequent transmission of CXCR4-using viruses. Apparently, the capacity of R5X4 viruses to use either co-receptor compromises the interaction with CCR5. Indeed, the $\beta$-chemokines preferentially inhibit the dual tropic virus isolates compared to R5 viruses when grown in cell lines expressing only CCR5 [86]. Moreover it has been shown that infection with R5X4 is affected by amino acids substitutions throughout the extracellular domains of CCR5 [87,88], whereas infection with $\mathrm{R} 5$ viruses mainly by changes in the $\mathrm{N}$-terminus of CCR5 [89].

Last, an alternative hypothesis is that both R5 and X4 viruses are transmitted, but the latter ones are subsequently sequestered or selectively eliminated [90,91]. Some studies suggested that CXCR4-using viruses isolated during the acute phase of infection were quickly 
suppressed in favour of R5 variants through an immune mechanism [92,93]. Although neutralizing antibodies were supposed to be involved, R5 and X4 viruses were shown to have similar sensitivity to neutralization [9496].

\section{Phenotype variation during disease progression}

Although R5 variants generally initiate infection and predominate in the early phase of the disease [42,5561 ], during the disease course in about one-half of HIV1 subtype $\mathrm{B}$ infected individuals the virus phenotype evolves from CCR5 to CXCR4-usage [97-99]. Two closely related questions are topic of a long lasting discussion. First, why do CXCR4-using viruses appear and dominate only late in infection, and second why is their appearance linked to a more rapid disease progression.

The general immune activation occurring in later stages of infection may result in the proliferation of naïve cells, which are preferentially infected by CXCR4-using variants [100]. Blaak et al. demonstrated that the frequency of HIV-1-infected naïve cells correlated with the rate of overall CD4+ T cell decline [73]. These studies suggest that $\mathrm{X} 4$ variants may arise due to a limited number of available CCR5+ target cells or, alternatively, because of the high number of CXCR4+ naive cell.

For a long time, it has been clear that the emergence of CXCR4-using viral variants is linked to an increased drop in the CD4+ T cell count $[97,98]$ and is predictive of a poor prognosis in adults and children [101104], suggesting that co-receptor usage strongly influence disease progression. Several mechanisms have been proposed. CXCR4-using viruses were described as more virulent than $\mathrm{R} 5$ viruses, with an increased cytopatogenicity and replication rate [24,105-108]. The ability of CXCR4-using viruses to infect thymocytes, the precursor cells of mature CD4+ T lymphocyte, may affect thymopoiesis and account for the accelerated T-cell decline [109]. Immature thymocytes express high levels of CXCR4 but almost no CCR5, and thus can preferentially be infected with CXCR4-using variants [110]. This hypothesis is corroborated by the finding that naïve $\mathrm{CD} 8+\mathrm{T}$ cells are somewhat reduced in patients with X4 variants as compared to patients with only R5 variants, which may suggest that infection and depletion of the precursor cells occurred [111].

The hypothesis of the "immune-control" to address the co-receptor switch has been recently re- viewed [112]. In accordance with this hypothesis, X4 viruses are better recognized by the immune system than R5 viruses and, consequently, better suppressed. In a recent study, Mild et al. hypothesized that the frequently observed intrapatient recombination of R5 and $\mathrm{X} 4$ virus variants, may result in virus variants with the potential to evade the immune system and also to better infect CXCR4-expressing cells [113]. This could easily contribute to the emergence of X4 viruses in the later stages of infection.

It remains to be explained why $\mathrm{R} 5$ viruses persist during the entire course of the disease and cause CD4+ $\mathrm{T}$ cell depletion and AIDS in the other half of subtype B infected individuals. In addition, the phenotypic switch to CXCR4-usage occurs only in rare cases among subtype $\mathrm{C}$ individuals [114,115]. R5 viruses isolated from AIDS patients ("late" R5) displayed an enhanced cytophatic effect compared to R5 viruses isolated from the same individuals at the early stage of disease ("early" R5) [116]. This enhanced cytophatic effect was paralleled by a decreased sensitivity to inhibition by the $\beta$-chemokine RANTES $[117,118]$. In addition these "late" R5 viruses were also more resistant to entry inhibitors and required lower expression levels of CD4/CCR5 [119].

Recently, it was shown that "early" R5 viruses have an R5 ${ }^{\text {narrow }}$ phenotype, as they are able to exclusively use the wild-type CCR5 for entry into target cells. During disease progression, $\mathrm{R} 5^{\text {broad }}$ viruses able to use CCR5/CXCR4 chimeric receptors emerge. The ability to use chimeric receptor was linked to an increased efficiency in CCR5 usage. The evolution from R5 narrow to $\mathrm{R} 5^{\text {broad }}$ phenotype was significantly associated with CD4+ T cell decline and with an increased resistance to inhibition by RANTES [29]. Thus, R5 viruses may evolve during the course of the disease towards more efficient CCR5 usage, which confers increased affinity for CCR5, enhancing the CD4-CCR5 interaction. This may favour an increased resistance to inhibition with the natural ligands and possibly an increased ability to infect target cells with low receptor density. In turn, this may result in a larger repertoire of available target cells and thereby increased cytopathogenicity and a more rapid disease progression (Fig. 2).

\section{Relevance of co-receptor and chemokine genetic polymorphisms for transmission, replication and pathogenesis}

Additional evidences supporting the role of R5 viruses in HIV-1 transmission came from genetic studies an- 
Early R5 HIV-1

R5narrow

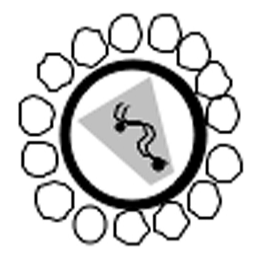

Late R5 HIV-1

R5broad

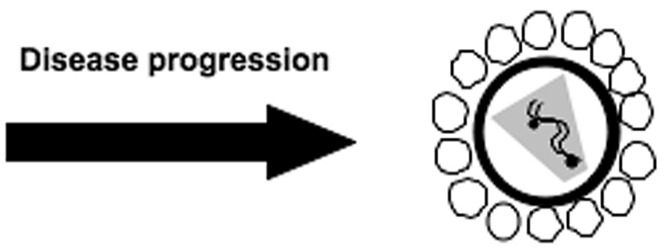

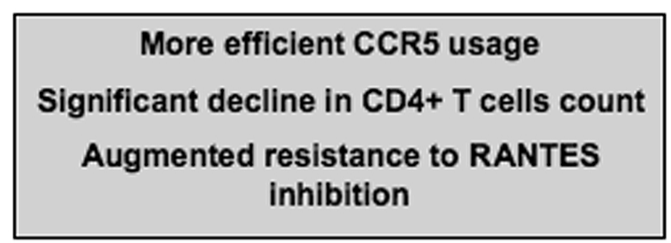

Fig. 2. Model of R5 viruses evolution during disease progression. R5 phenotype evolves during the pathogenic process from R5narrow to R5broad. The phenotypic variation is characterized by a more flexible and efficient use of the CCR5 co-receptor, which correlates with CD4+ T cells decline and increased resistance to RANTES inhibition.

alyzing polymorphisms in CCR5 gene. Particularly interesting is a 32-nucleotide deletion $(\Delta 32)$ that renders the CCR5 co-receptor non functional [120-122]. Cells from CCR5 $\Delta 32$ homozygotes are highly resistant to in vitro infection with $\mathrm{R} 5$ variants but permissive for $\mathrm{X} 4$ variants or dual tropic strains [12,120,122]. The incidence of the $\triangle 32$ CCR5 allele is high in Caucasian population, approximate $1 \%$ are homozygous and $20 \%$ heterozygous, but appears only sporadically in Asian and African populations [12].

Studies on large cohorts of individuals exposed to HIV-1 either sexually, parenterally, or via mother-tochild (MTCT) transmission, described that the homozygous mutation confers high level of resistance to infection [120,123-127]. However, protection is not absolute and some rare cases of HIV-1 infection despite this genotype have been reported [128-131]. These patients harboured CXCR4-using viruses, suggesting that CXCR4 was the co-receptor responsible for initiating infection.

Individuals heterozygous for the mutation express lower levels of CCR5 [38] but remain susceptible to HIV-1 infection. The frequency of $\Delta 32$ CCR5 heterozygotes in highly exposed but uninfected individuals is similar to that in the seropositive population [123, 124,132-134]. Exceptions have been reported in three studies, two of adults and one of infants, suggesting a reduced risk of transmission inferred by the heterozygous mutation $[12,135,136]$. However, heterozygous individuals display a slower progression towards
AIDS $[123,132,133,137,138]$, characterized by a slower decline of CD4+ T cells and a lower viral load [139].

A series of studies showed that the same 32-basepair deletion of the CCR5 gene, when detected in the HIV1 infected mother, does not correlate with transmission $[135,136,140-145]$. It appears, however, to exert a protective effect against MTCT transmission in those children exposed to a low maternal viral burden of an R5-type isolate [146]. The lack of association between $\triangle 32$ CCR5 heterozygosity and the risk of vertical transmission suggests that HIV-1 could utilizes a receptor other than CCR5 to infect cells present at the fetus/infant's mucosal sites. Indeed alternative receptors used by HIV-1 have been identified on mucosal epithelial cells [147-150]. An international meta-analysis study associated the $\Delta 32$ CCR5 polymorphism with a decreased risk of death among perinatally infected children, but only for the first year of life [151].

Additional polymorphisms in the CCR5 gene have been identified, the majority of which are single amino acid substitutions. McDermott et al. identified an A/G polymorphism at basepair 59029 of the CCR5 promoter [152], which was associated with a delayed progression to AIDS in a cohort of HIV-1 seroconvertors lacking both $\triangle 32$ CCR5 and CCR2-641. Conversely, another polymorphism in the CCR5 promoter region, defined CCR5 P1, was shown to accelerate disease progression in homozygous individuals [153]. Finally a mutation (m303) that causes a premature stop codon that prevents the expression of CCR5 appears to con- 
fer resistance to an individual carrying the 32-basepair deletion [154]. Additional mutations in the CCR5 gene have been reported, however their influence on HIV-1 in vivo is not clear [155-157].

Polymorphisms in receptors other than CCR5 have been identified. A single nucleotide mutation in the CCR2 receptor which results in the substitution of a valine residue for an isoleucine at position 65 (CCR2-64I) has no effect on sexual transmission [158], but exerts a protective effect on MTCT and on disease progression in perinatally infected children $[151,159]$.

A homozygous mutation at position 881 of the 3'untranslated region of the SDF-1 gene (SDF-1 3'A), which encodes the ligand for CXCR4, was shown to protect adults exposed to HIV-1 from infection and to delay disease progression [160]. However, several subsequent studies showed a correlation between the presence of the mutated allele and accelerated progression of HIV-1 infection to AIDS or death [161-164]. With regard to pediatric HIV-1 infection, one study has shown that the mother's, but not the infant's SDF-1 genotype was associated with MTCT [165] and another showed that the protective effect of the heterozygous form of the $\Delta 32$ CCR5 was restricted by the SDF-1 genotype in HIV-1 infected children [166]. We have shown that the presence of the SDF-1 3'A gene correlates with accelerated disease progression in HIV-1infected children born to seropositive mothers but does not protect against MTCT of HIV-1 [167].

A rapid progression to AIDS was reported in HIV1 infected individuals with a structural variant of the chemokine receptor CX3CR1, used by HIV-1 as coreceptor in the Central Nervous System [168]. Patients homozygous for CX3CR1-I249 and M280, a variant haplotype affecting two amino acids (isoleucine-249 and methionine-280) progressed to AIDS more rapidly than those with other haplotypes. However, children with the CX3CR1-I249 genotype experienced more rapid disease progression compared to those with the CX3CR1-I249 M280 haplotype [169].

\section{Viral phenotype as a marker to predict HIV-1 mother-to-child transmission and pediatric disease progression}

Viral genotype and phenotype have given little evidence of a specific pattern associated with MTCT of HIV-1. We and other groups have studied the correlation between co-receptor usage and risk of transmission, and have described that most maternal isolates are able to use CCR5 as co-receptor, either alone or in association with CXCR4 or other chemokine receptors, independently from transmission (reviewed in [170]). Thus, CCR5 usage is not a useful predictive marker of transmission. Conversely, in an earlier study we showed that mothers who harbour virus with high replicative and SI capacity (R5X4/X4 virus) had a significant higher risk to infect their children than mothers with slow/low (R5) virus [58]. Most vertical transmissions occurred with CCR5-using viruses irrespective of HIV-1 genetic subtype [55,57,58,62].

Recently we took in consideration the possibility that $\mathrm{R} 5^{\text {broad }}$ viruses with a more flexible use of CCR5 coreceptor could influence MTCT of HIV-1. Although the R5 ${ }^{\text {broad }}$ phenotype was not linked to higher risk of transmission, we demonstrated that the maternal viral phenotype (either R5 ${ }^{\text {narrow }}$ or R5 $5^{\text {broad }}$ ) is generally preserved during transmission and can possibly be predictive of the phenotype of the newborn's viral variant [171]. On the contrary, the R5X4 phenotype was predominantly lost during transmission. Several reports showed that $\mathrm{X} 4$ viruses can be transmitted to the newborn, but only in a limited number of cases. In our studies, this low frequency of transmission was closely related to the rare presence of $\mathrm{X} 4$ viruses in transmitting mothers [58].

Our data suggested that mothers carrying R5X4 viruses had phenotypically highly heterogenous populations. We documented the transmission of multiple viral variants with different co-receptor usage in a $\Delta 32$ CCR5 heterozygous child, and demonstrated that the heterozygous genotype per se does not contributed to the restriction of R5-type virus spread [172]. It remains to be solved why CXCR4 using viruses are not preferentially maintained during transmission, despite the high prevalence of CXCR4+ naïve T cells in neonates compared to memory CCR5+ CD4+ T cells [173]. Whether a selective process or simply a random event governs transmission remains, however, a topic of discussion [57,97,174,175].

It is intriguing that the early stage of pediatric HIV-1 infection was characterized by an R5 ${ }^{\text {broad }}$ phenotype, which in adults appeared only at an advanced stage of the disease. This means that infection in children can be establish by viral variants with an $e n v$ conformation that allows for a more efficient CCR5 use. In addition, the $\mathrm{R} 5^{\text {broad }}$ phenotype was shown to be a new predictive marker of rapid disease progression and early immunological failure in infected children [171]. R5 broad viruses seem to determine detrimental effects similar to those known for CXCR4 using viruses. These data sup- 
Table 1

Changes within R5 phenotype over time in two children

\begin{tabular}{llllllll}
\hline $\begin{array}{c}\text { Age } \\
\text { code } \\
\text { (months) }\end{array}$ & CCR5 & CXCR4 & FC-1 & FC-2 & FC-4b \\
\hline
\end{tabular}

A

13
19
26
34
42

9
16
40
46
52
67

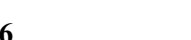

13

$26-$

Infection of U87.CD4 cells expressing CCR5, CXCR4 or one of the chimeric receptors FC1, FC2 or FC-4b with sequential virus isolates from two siblings.

+ denotes viruses using the specific coreceptor

port the finding by Casper et al, who suggested that the immunological deterioration in HIV-1 infected children precedes the viral phenotypic switch to CXCR4 usage [101]. We suggest that pre-existing R5 ${ }^{\text {broad }}$ viruses may have caused the worsening of the disease. Interestingly, in our study all but one newborn's R5 ${ }^{\text {broad }}$ viruses were capable of a specific chimeric receptor usage (FC-4b), which was previously shown to be linked to evolution to CXCR4 use in adults [29].

Evolution to CXCR4 receptor usage was repeatedly documented in infected children [55,103]. If the appearance of CXCR4-using variants over time is due to an early inhibition of transmitted virus or viral evolution is not defined yet. Phylogenetic studies of two mother-child pairs revealed that the appearing X4 virus in the child was due to viral evolution from their own R5 population rather than caused by transmission of the mother's X4 strain [176].

We have recently reported that viral isolates of infected children display an R5 phenotypic evolution during disease progression [177]. The children were infected with HIV-1 of R5 phenotype, which persisted throughout follow-up, but evolved to better utilize CCR5 over time (Table 1). This phenotypic evolution from wildtype R5 to broad chimeric receptor using viruses was also characterized by an increase of RANTES resistance in vitro [177]. Our hypothesis is that the reduced sensitivity to RANTES inhibition of R5 ${ }^{\text {broad }}$ viruses could became the force driving the viral evolution to CXCR4 usage. The different sensitivity of R5 $5^{\text {broad }}$ viruses to RANTES should be investigated in the view of treatments with small CCR5 entry inhibitors.

\section{Concluding remarks}

Since the discovery of chemokine receptors as HIV1 co-receptors, promising new strategies for the development of anti-HIV-1 agents and vaccines have been envisaged. One of the most promising approaches has been to interfere with HIV-1 co-receptor binding with chemokines-derivatives/analogouses. As individuals with the $\Delta 32$ homozygote condition appear to be healthy, and the CCR5 function redundant, several compounds directed against CCR5 have been developed in the last years, including covalently modified natural CCR5 ligands, antibodies and small-molecule antagonists. One of these inhibitors (maraviroc, Pfizer, Inc.) has been approved for clinical use, a second (vicriviroc, Schering-Plough Research Institute) is in phase 3 trials, and several others are in preclinical or clinical development (for review see [178]). However it is not clear whether such antagonistic agents could favour the emergence of the more pathogenic CXCR4- 
using viruses or variants that exploit alternative coreceptors. Thus, HIV-1 phenotyping becomes mandatory with the introduction of these drugs. However, the principal resistance pathway to CCR5 antagonists was shown in vitro to involve CCR5 usage in an inhibitor resistant manner [179], without switch to CXCR4 usage. If the sub-classification of R5 viruses in narrow and broad could explain this resistance in vivo, has still to be investigated.

Small positively charged peptides have also been reported that interact with CXCR4 and block infection of X4 strains [180,181]. Among CXCR4 antagonists, AMD070 is currently the unique molecule in clinical development and phase $1 \mathrm{~b} / 2 \mathrm{a}$ clinical trials are ongoing [182].

A recently described successful transplantation of allogeneic stem cells homozygous for the CCR5 delta32 allele to a patient with HIV, who subsequently controlled the infection in absence of antiretroviral therapy supports further development of CCR5-directed drugs or vaccines [183].

\section{Acknowledgements}

The financial support of the Istituto Superiore di Sanità (Grant no. 40G.56) and of the Melinda and Bill Gates Foundation (Grant FHG3858) are gratefully acknowledged.

\section{References}

[1] A.G. Dalgleish, P.C. Beverley, P.R. Clapham, D.H. Crawford, M.F. Greaves and R.A. Weiss, The CD4 (T4) antigen is an essential component of the receptor for the AIDS retrovirus, Nature 312 (1984), 763-767.

[2] P.J. Maddon, A.G. Dalgleish, J.S. McDougal, P.R. Clapham, R.A. Weiss and R. Axel, The T4 gene encodes the AIDS virus receptor and is expressed in the immune system and the brain, Cell 47 (1986), 333-348.

[3] P.J. Maddon, D.R. Littman, M. Godfrey, D.E. Maddon, L. Chess and R. Axel, The isolation and nucleotide sequence of a cDNA encoding the $\mathrm{T}$ cell surface protein $\mathrm{T} 4$ : a new member of the immunoglobulin gene family, Cell 42 (1985), 93-104.

[4] P.A. Ashorn, E.A. Berger and B. Moss, Human immunodeficiency virus envelope glycoprotein/CD4-mediated fusion of nonprimate cells with human cells, J Virol 64 (1990), 2149_ 2156.

[5] K.A. Page, N.R. Landau and D.R. Littman, Construction and use of a human immunodeficiency virus vector for analysis of virus infectivity, J Virol 64 (1990), 5270-5276.

[6] E.A. Berger, HIV entry and tropism: the chemokine receptor connection, AIDS 11 Suppl A (1997), S3-S16.
[7] F. Cocchi, A.L. DeVico, A. Garzino-Demo, S.K. Arya, R.C. Gallo and P. Lusso, Identification of RANTES, MIP-1 alpha, and MIP-1 beta as the major HIV-suppressive factors produced by CD8+ T cells, Science 270 (1995), 1811-1815.

[8] Y. Feng, C.C. Broder, P.E. Kennedy and E.A. Berger, HIV1 entry cofactor: functional cDNA cloning of a seventransmembrane, G protein-coupled receptor, Science $\mathbf{2 7 2}$ (1996), 872-877.

[9] C.C. Bleul, M. Farzan, H. Choe, C. Parolin, I. Clark-Lewis, J. Sodroski and T.A. Springer, The lymphocyte chemoattractant SDF-1 is a ligand for LESTR/fusin and blocks HIV-1 entry, Nature 382 (1996), 829-833.

[10] E. Oberlin, A. Amara, F. Bachelerie, C. Bessia, J.L. Virelizier, F. Arenzana-Seisdedos, O. Schwartz, J.M. Heard, I. Clark-Lewis, D.F. Legler, M. Loetscher, M. Baggiolini and B. Moser, The CXC chemokine SDF-1 is the ligand for LESTR/fusin and prevents infection by T-cell-line-adapted HIV-1, Nature 382 (1996), 833-835.

[11] C. Combadiere, S.K. Ahuja, H.L. Tiffany and P.M. Murphy, Cloning and functional expression of CC CKR5, a human monocyte CC chemokine receptor selective for MIP1(alpha), MIP-1(beta), and RANTES, J Leukoc Biol 60 (1996), 147-152.

[12] M. Samson, O. Labbe, C. Mollereau, G. Vassart and M. Parmentier, Molecular cloning and functional expression of a new human CC-chemokine receptor gene, Biochemistry 35 (1996), 3362-3367.

[13] G. Alkhatib, C. Combadiere, C.C. Broder, Y. Feng, P.E. Kennedy, P.M. Murphy and E.A. Berger, CC CKR5: a RANTES, MIP-1alpha, MIP-1beta receptor as a fusion cofactor for macrophage-tropic HIV-1, Science 272 (1996), 1955-1958.

[14] H. Choe, M. Farzan, Y. Sun, N. Sullivan, B. Rollins, P.D. Ponath, L. Wu, C.R. Mackay, G. LaRosa, W. Newman, N. Gerard, C. Gerard and J. Sodroski, The beta-chemokine receptors CCR 3 and CCR5 facilitate infection by primary HIV1 isolates, Cell 85 (1996), 1135-1148.

[15] H. Deng, R. Liu, W. Ellmeier, S. Choe, D. Unutmaz, M. Burkhart, P. Di Marzio, S. Marmon, R.E. Sutton, C.M. Hill, C.B. Davis, S.C. Peiper, T.J. Schall, D.R. Littman and N.R. Landau, Identification of a major co-receptor for primary isolates of HIV-1, Nature 381 (1996), 661-666.

[16] T. Dragic, V. Litwin, G.P. Allaway, S.R. Martin, Y. Huang, K.A. Nagashima, C. Cayanan, P.J. Maddon, R.A. Koup, J.P. Moore and W.A. Paxton, HIV-1 entry into CD4+ cells is mediated by the chemokine receptor CC-CKR-5, Nature 381 (1996), 667-673.

[17] H. Choe, M. Farzan, M. Konkel, K. Martin, Y. Sun, L. Marcon, M. Cayabyab, M. Berman, M.E. Dorf, N. Gerard, C. Gerard and J. Sodroski, The orphan seven-transmembrane receptor apj supports the entry of primary T-cell-line-tropic and dualtropic human immunodeficiency virus type $1, J$ Virol 72 (1998), 6113-6118.

[18] H.K. Deng, D. Unutmaz, V.N. KewalRamani and D.R. Littman, Expression cloning of new receptors used by simian and human immunodeficiency viruses, Nature 388 (1997), 296-300.

[19] B.J. Doranz, J. Rucker, Y. Yi, R.J. Smyth, M. Samson, S.C. Peiper, M. Parmentier, R.G. Collman and R.W. Doms, A dual-tropic primary HIV-1 isolate that uses fusin and the betachemokine receptors CKR-5, CKR-3, and CKR-2b as fusion cofactors, Cell 85 (1996), 1149-1158.

[20] A. Jinno, N. Shimizu, Y. Soda, Y. Haraguchi, T. Kitamura and H. Hoshino, Identification of the chemokine receptor 
TER1/CCR8 expressed in brain-derived cells and T cells as a new coreceptor for HIV-1 infection, Biochem Biophys Res Commun 243 (1998), 497-502.

[21] S.M. Owen, D. Ellenberger, M. Rayfield, S. Wiktor, P. Michel, M.H. Grieco, F. Gao, B.H. Hahn and R.B. Lal, Genetically divergent strains of human immunodeficiency virus type 2 use multiple coreceptors for viral entry, J Virol $\mathbf{7 2}$ (1998), 5425-5432.

[22] B.J. Rollins, Chemokines, Blood 90 (1997), 909-928.

[23] M. Samson, A.L. Edinger, P. Stordeur, J. Rucker, V. Verhasselt, M. Sharron, C. Govaerts, C. Mollereau, G. Vassart, R.W. Doms and M. Parmentier, ChemR23, a putative chemoattractant receptor, is expressed in monocyte-derived dendritic cells and macrophages and is a coreceptor for SIV and some primary HIV-1 strains, Eur J Immunol 28 (1998), 1689-1700.

[24] B. Asjo, L. Morfeldt-Manson, J. Albert, G. Biberfeld, A. Karlsson, K. Lidman and E.M. Fenyo, Replicative capacity of human immunodeficiency virus from patients with varying severity of HIV infection, Lancet 2 (1986), 660-662.

[25] S. Gartner, P. Markovits, D.M. Markovitz, M.H. Kaplan, R.C. Gallo and M. Popovic, The role of mononuclear phagocytes in HTLV-III/LAV infection, Science 233 (1986), 215-219.

[26] M. Tersmette, R.E. de Goede, B.J. Al, I.N. Winkel, R.A. Gruters, H.T. Cuypers, H.G. Huisman and F. Miedema, Differential syncytium-inducing capacity of human immunodeficiency virus isolates: frequent detection of syncytiuminducing isolates in patients with acquired immunodeficiency syndrome (AIDS) and AIDS-related complex, J Virol 62 (1988), 2026-2032.

[27] T.L. Hoffman and R.W. Doms, HIV-1 envelope determinants for cell tropism and chemokine receptor use, Mol Membr Biol 16 (1999), 57-65.

[28] E.A. Berger, R.W. Doms, E.M. Fenyo, B.T. Korber, D.R. Littman, J.P. Moore, Q.J. Sattentau, H. Schuitemaker, J. Sodroski and R.A. Weiss, A new classification for HIV-1, $\mathrm{Na}$ ture 391 (1998), 240.

[29] I. Karlsson, L. Antonsson, Y. Shi, M. Oberg, A. Karlsson, J. Albert, B. Olde, C. Owman, M. Jansson and E.M. Fenyo, Coevolution of RANTES sensitivity and mode of CCR5 receptor use by human immunodeficiency virus type 1 of the R5 phenotype, J Virol 78 (2004), 11807-11815.

[30] A. McKnight, M.T. Dittmar, J. Moniz-Periera, K. Ariyoshi, J.D. Reeves, S. Hibbitts, D. Whitby, E. Aarons, A.E. Proudfoot, H. Whittle and P.R. Clapham, A broad range of chemokine receptors are used by primary isolates of human immunodeficiency virus type 2 as coreceptors with CD4, $J$ Virol 72 (1998), 4065-4071.

[31] A. Valentin, H. Trivedi, W. Lu, L.G. Kostrikis and G.N. Pavlakis, CXCR4 mediates entry and productive infection of syncytia-inducing (X4) HIV-1 strains in primary macrophages, Virology 269 (2000), 294-304.

[32] Y. Yi, S. Rana, J.D. Turner, N. Gaddis and R.G. Collman, CXCR-4 is expressed by primary macrophages and supports CCR5-independent infection by dual-tropic but not T-tropic isolates of human immunodeficiency virus type $1, J$ Virol 72 (1998), 772-777.

[33] G. Alkhatib, C.C. Broder and E.A. Berger, Cell type-specific fusion cofactors determine human immunodeficiency virus type 1 tropism for T-cell lines versus primary macrophages, J Virol 70 (1996), 5487-5494.

[34] R.I. Connor, W.A. Paxton, K.E. Sheridan and R.A. Koup, Macrophages and CD4+ T lymphocytes from two multiply exposed, uninfected individuals resist infection with primary non-syncytium-inducing isolates of human immunodeficiency virus type 1, J Virol 70 (1996), 8758-8764.

[35] R.A. Fouchier, M. Brouwer, N.A. Kootstra, H.G. Huisman and H. Schuitemaker, HIV-1 macrophage tropism is determined at multiple levels of the viral replication cycle, J Clin Invest 94 (1994), 1806-1814.

[36] J.C. Grivel, M.L. Penn, D.A. Eckstein, B. Schramm, R.F. Speck, N.W. Abbey, B. Herndier, L. Margolis and M.A. Goldsmith, Human immunodeficiency virus type 1 coreceptor preferences determine target T-cell depletion and cellular tropism in human lymphoid tissue, J Virol 74 (2000), 5347-5351.

[37] H.M. Naif, S. Li, M. Alali, A. Sloane, L. Wu, M. Kelly, G. Lynch, A. Lloyd and A.L. Cunningham, CCR5 expression correlates with susceptibility of maturing monocytes to human immunodeficiency virus type 1 infection, $J$ Virol 72 (1998), 830-836.

[38] L. Wu, W.A. Paxton, N. Kassam, N. Ruffing, J.B. Rottman, N. Sullivan, H. Choe, J. Sodroski, W. Newman, R.A. Koup and C.R. Mackay, CCR5 levels and expression pattern correlate with infectability by macrophage-tropic HIV-1, in vitro, J Exp Med 185 (1997), 1681-1691.

[39] C. Cheng-Mayer, R. Liu, N.R. Landau and L. Stamatatos, Macrophage tropism of human immunodeficiency virus type 1 and utilization of the CC-CKR5 coreceptor, J Virol 71 (1997), 1657-1661.

[40] M.T. Dittmar, A. McKnight, G. Simmons, P.R. Clapham, R.A. Weiss and P. Simmonds, HIV-1 tropism and co-receptor use, Nature 385 (1997), 495-496.

[41] E. Karita, J.N. Nkengasong, B. Willems, G. Vanham, K. Fransen, L. Heyndrickx, W. Janssens, P. Piot and G. van der Groen, Macrophage-tropism of HIV-1 isolates of different genetic subtypes, AIDS 11 (1997), 1303-1304.

[42] H. Schuitemaker, N.A. Kootstra, R.E. de Goede, F. de Wolf, F. Miedema and M. Tersmette, Monocytotropic human immunodeficiency virus type 1 (HIV-1) variants detectable in all stages of HIV-1 infection lack T-cell line tropism and syncytium-inducing ability in primary T-cell culture, $J$ Virol 65 (1991), 356-363.

[43] S.L. Kozak, E.J. Platt, N. Madani, F.E. Ferro, Jr., K. Peden and D. Kabat, CD4, CXCR-4, and CCR-5 dependencies for infections by primary patient and laboratory-adapted isolates of human immunodeficiency virus type 1, J Virol 71 (1997), 873-882.

[44] E.J. Platt, K. Wehrly, S.E. Kuhmann, B. Chesebro and D. Kabat, Effects of CCR5 and CD4 cell surface concentrations on infections by macrophagetropic isolates of human immunodeficiency virus type 1, J Virol 72 (1998), 2855-2864.

[45] D.S. Dimitrov, D. Norwood, T.S. Stantchev, Y. Feng, X. Xiao and C.C. Broder, A mechanism of resistance to HIV-1 entry: inefficient interactions of CXCR4 with CD4 and gp120 in macrophages, Virology 259 (1999), 1-6.

[46] K. Tokunaga, M.L. Greenberg, M.A. Morse, R.I. Cumming, H.K. Lyerly and B.R. Cullen, Molecular basis for cell tropism of CXCR4-dependent human immunodeficiency virus type 1 isolates, $J$ Virol 75 (2001), 6776-6785.

[47] G. Simmons, D. Wilkinson, J.D. Reeves, M.T. Dittmar, S. Beddows, J. Weber, G. Carnegie, U. Desselberger, P.W. Gray, R.A. Weiss and P.R. Clapham, Primary, syncytium-inducing human immunodeficiency virus type 1 isolates are dual-tropic and most can use either Lestr or CCR5 as coreceptors for virus entry, J Virol 70 (1996), 8355-8360.

[48] A. Valentin, J. Albert, E.M. Fenyo and B. Asjo, Dual tropism for macrophages and lymphocytes is a common feature of 
primary human immunodeficiency virus type 1 and 2 isolates, J Virol 68 (1994), 6684-6689.

[49] H.A. Bazan, G. Alkhatib, C.C. Broder and E.A. Berger, Patterns of CCR5, CXCR4, and CCR3 usage by envelope glycoproteins from human immunodeficiency virus type 1 primary isolates, J Virol 72 (1998), 4485-4491.

[50] R.G. Collman and Y. Yi, Cofactors for human immunodeficiency virus entry into primary macrophages, $J$ Infect Dis 179 Suppl 3 (1999), S422-S426.

[51] F. Baribaud and R.W. Doms, The impact of chemokine receptor conformational heterogeneity on HIV infection, Cell Mol Biol (Noisy-le-grand) 47 (2001), 653-660.

[52] J.W. Balliet, D.L. Kolson, G. Eiger, F.M. Kim, K.A. McGann, A. Srinivasan and R. Collman, Distinct effects in primary macrophages and lymphocytes of the human immunodeficiency virus type 1 accessory genes vpr, vpu, and nef: mutational analysis of a primary HIV-1 isolate, Virology 200 (1994), 623-631.

[53] D. Gabuzda, J. He, A. Ohagen and A.V. Vallat, Chemokine receptors in HIV-1 infection of the central nervous system, Semin Immunol 10 (1998), 203-213.

[54] M. Kawamura, T. Ishizaki, A. Ishimoto, T. Shioda, T. Kitamura and A. Adachi, Growth ability of human immunodeficiency virus type 1 auxiliary gene mutants in primary blood macrophage cultures, J Gen Virol 75 (Pt 9) (1994), 2427-2431.

[55] C.H. Casper, P. Clevestig, E. Carlenor, T. Leitner, B. Anzen, K. Lidman, E. Belfrage, J. Albert, A.B. Bohlin, L. Naver, S. Lindgren, E.M. Fenyo and A.C. Ehrnst, Link between the X4 phenotype in human immunodeficiency virus type 1-infected mothers and their children, despite the early presence of R5 in the child, J Infect Dis 186 (2002), 914-921.

[56] R.N. Husson, Y. Lan, E. Kojima, D. Venzon, H. Mitsuya and K. McIntosh, Vertical transmission of human immunodeficiency virus type 1: autologous neutralizing antibody, virus load, and virus phenotype, J Pediatr 126 (1995), 865-871.

[57] L. Ometto, C. Zanotto, A. Maccabruni, D. Caselli, D. Truscia, C. Giaquinto, E. Ruga, L. Chieco-Bianchi and A. De Rossi, Viral phenotype and host-cell susceptibility to HIV-1 infection as risk factors for mother-to-child HIV-1 transmission, AIDS 9 (1995), 427-434.

[58] G. Scarlatti, V. Hodara, P. Rossi, L. Muggiasca, A. Bucceri, J. Albert and E.M. Fenyo, Transmission of human immunodeficiency virus type 1 (HIV-1) from mother to child correlates with viral phenotype, Virology 197 (1993), 624-629.

[59] C. Tscherning-Casper, D. Vodros, E. Menu, K. Aperia, R. Fredriksson, G. Dolcini, G. Chaouat, F. Barre-Sinoussi, J. Albert and E.M. Fenyo, Coreceptor usage of HIV-1 isolates representing different genetic subtypes obtained from pregnant Cameroonian women. European Network for In Utero Transmission of HIV-1, J Acquir Immune Defic Syndr 24 (2000), 1-9.

[60] A.B. van't Wout, N.A. Kootstra, G.A. Mulder-Kampinga, N. Albrecht-van Lent, H.J. Scherpbier, J. Veenstra, K. Boer, R.A. Coutinho, F. Miedema and H. Schuitemaker, Macrophage-tropic variants initiate human immunodeficiency virus type 1 infection after sexual, parenteral, and vertical transmission, J Clin Invest 94 (1994), 2060-2067.

[61] T. Zhu, H. Mo, N. Wang, D.S. Nam, Y. Cao, R.A. Koup and D.D. Ho, Genotypic and phenotypic characterization of HIV-1 patients with primary infection, Science 261 (1993), 1179-1181.

[62] A. De Rossi, L. Ometto, S. Masiero, M. Zanchetta and L. Chieco-Bianchi, Viral phenotype in mother-to-child HIV-1 transmission and disease progression of vertically acquired HIV-1 infection, Acta Paediatr Suppl 421 (1997), 22-28.

[63] E.M. Long, S.M. Rainwater, L. Lavreys, K. Mandaliya and J. Overbaugh, HIV type 1 variants transmitted to women in Kenya require the CCR5 coreceptor for entry, regardless of the genetic complexity of the infecting virus, AIDS Res Hum Retroviruses 18 (2002), 567-576.

[64] S. Ayehunie, E.A. Garcia-Zepeda, J.A. Hoxie, R. Horuk, T.S. Kupper, A.D. Luster and R.M. Ruprecht, Human immunodeficiency virus-1 entry into purified blood dendritic cells through CC and CXC chemokine coreceptors, Blood $\mathbf{9 0}$ (1997), 1379-1386.

[65] M.T. Dittmar, G. Simmons, S. Hibbitts, M. O’Hare, S. Louisirirotchanakul, S. Beddows, J. Weber, P.R. Clapham and R.A. Weiss, Langerhans cell tropism of human immunodeficiency virus type 1 subtype A through F isolates derived from different transmission groups, J Virol 71 (1997), 8008-8013.

[66] A. Granelli-Piperno, B. Moser, M. Pope, D. Chen, Y. Wei, F. Isdell, U. O’Doherty, W. Paxton, R. Koup, S. Mojsov, N. Bhardwaj, I. Clark-Lewis, M. Baggiolini and R.M. Steinman, Efficient interaction of HIV-1 with purified dendritic cells via multiple chemokine coreceptors, J Exp Med 184 (1996), 2433-2438.

[67] A. Rubbert, C. Combadiere, M. Ostrowski, J. Arthos, M. Dybul, E. Machado, M.A. Cohn, J.A. Hoxie, P.M. Murphy, A.S. Fauci and D. Weissman, Dendritic cells express multiple chemokine receptors used as coreceptors for HIV entry, $J$ Immunol 160 (1998), 3933-3941.

[68] M. Zaitseva, A. Blauvelt, S. Lee, C.K. Lapham, V. KlausKovtun, H. Mostowski, J. Manischewitz and H. Golding, Expression and function of CCR5 and CXCR4 on human Langerhans cells and macrophages: implications for HIV primary infection, Nat Med 3 (1997), 1369-1375.

[69] A.I. Spira, P.A. Marx, B.K. Patterson, J. Mahoney, R.A. Koup, S.M. Wolinsky and D.D. Ho, Cellular targets of infection and route of viral dissemination after an intravaginal inoculation of simian immunodeficiency virus into rhesus macaques, J Exp Med 183 (1996), 215-225.

[70] P. Cameron, M. Pope, A. Granelli-Piperno and R.M. Steinman, Dendritic cells and the replication of HIV-1, J Leukoc Biol 59 (1996), 158-171.

[71] T.B. Geijtenbeek, D.S. Kwon, R. Torensma, S.J. van Vliet, G.C. van Duijnhoven, J. Middel, I.L. Cornelissen, H.S. Nottet, V.N. KewalRamani, D.R. Littman, C.G. Figdor and Y. van Kooyk, DC-SIGN, a dendritic cell-specific HIV-1binding protein that enhances trans-infection of T cells, Cell 100 (2000), 587-597.

[72] R.P. van Rij, H. Blaak, J.A. Visser, M. Brouwer, R. Rientsma, S. Broersen, A.M. de Roda Husman and H. Schuitemaker, Differential coreceptor expression allows for independent evolution of non-syncytium-inducing and syncytiuminducing HIV-1, J Clin Invest 106 (2000), 1569.

[73] H. Blaak, A.B. van't Wout, M. Brouwer, B. Hooibrink, E. Hovenkamp and $\mathrm{H}$. Schuitemaker, In vivo HIV-1 infection of CD45RA(+)CD4(+) T cells is established primarily by syncytium-inducing variants and correlates with the rate of CD4(+) T cell decline, Proc Natl Acad Sci USA 97 (2000), 1269-1274.

[74] C.C. Bleul, L. Wu, J.A. Hoxie, T.A. Springer and C.R. Mackay, The HIV coreceptors CXCR4 and CCR5 are differentially expressed and regulated on human T lymphocytes, Proc Natl Acad Sci U S A 94 (1997), 1925-1930. 
[75] M.A. Ostrowski, T.W. Chun, S.J. Justement, I. Motola, M.A. Spinelli, J. Adelsberger, L.A. Ehler, S.B. Mizell, C.W. Hallahan and A.S. Fauci, Both memory and CD45RA+/CD62L+ naive $\mathrm{CD} 4(+) \mathrm{T}$ cells are infected in human immunodeficiency virus type 1-infected individuals, J Virol 73 (1999), 6430-6435.

[76] J.M. Brenchley, T.W. Schacker, L.E. Ruff, D.A. Price, J.H. Taylor, G.J. Beilman, P.L. Nguyen, A. Khoruts, M. Larson, A.T. Haase and D.C. Douek, CD4+ T cell depletion during all stages of HIV disease occurs predominantly in the gastrointestinal tract, J Exp Med 200 (2004), 749-759.

[77] S. Mehandru, M.A. Poles, K. Tenner-Racz, A. Horowitz, A Hurley, C. Hogan, D. Boden, P. Racz and M. Markowitz, Primary HIV-1 infection is associated with preferential depletion of CD4+ $\mathrm{T}$ lymphocytes from effector sites in the gastrointestinal tract, J Exp Med 200 (2004), 761-770.

[78] R.S. Veazey, M. DeMaria, L.V. Chalifoux, D.E. Shvetz, D.R Pauley, H.L. Knight, M. Rosenzweig, R.P. Johnson, R.C. Desrosiers and A.A. Lackner, Gastrointestinal tract as a major site of CD4+ T cell depletion and viral replication in SIV infection, Science 280 (1998), 427-431.

[79] M.K. Jenkins, A. Khoruts, E. Ingulli, D.L. Mueller, S.J. McSorley, R.L. Reinhardt, A. Itano and K.A. Pape, In vivo activation of antigen-specific CD4 T cells, Annu Rev Immunol 19 (2001), 23-45.

[80] M.I. Bukrinsky, T.L. Stanwick, M.P. Dempsey and M. Stevenson, Quiescent T lymphocytes as an inducible virus reservoir in HIV-1 infection, Science 254 (1991), 423-427.

[81] J.A. Zack, S.J. Arrigo, S.R. Weitsman, A.S. Go, A. Haislip and I.S. Chen, HIV-1 entry into quiescent primary lymphocytes: molecular analysis reveals a labile, latent viral structure, Cell 61 (1990), 213-222.

[82] J.A. Zack, A.M. Haislip, P. Krogstad and I.S. Chen, Incompletely reverse-transcribed human immunodeficiency virus type 1 genomes in quiescent cells can function as intermediates in the retroviral life cycle, J Virol 66 (1992), 1717-1725.

[83] W.W. Agace, A. Amara, A.I. Roberts, J.L. Pablos, S. Thelen, M. Uguccioni, X.Y. Li, J. Marsal, F. Arenzana-Seisdedos, T. Delaunay, E.C. Ebert, B. Moser and C.M. Parker, Constitutive expression of stromal derived factor-1 by mucosal epithelia and its role in HIV transmission and propagation, Curr Biol 10 (2000), 325-328.

[84] B.K. Patterson, A. Landay, J. Andersson, C. Brown, H. Behbahani, D. Jiyamapa, Z. Burki, D. Stanislawski, M.A. Czerniewski and P. Garcia, Repertoire of chemokine receptor expression in the female genital tract: implications for human immunodeficiency virus transmission, Am J Pathol 153 (1998), 481-490.

[85] J.B. Rottman, K.P. Ganley, K. Williams, L. Wu, C.R. Mackay and D.J. Ringler, Cellular localization of the chemokine receptor CCR5. Correlation to cellular targets of HIV-1 infection, Am J Pathol 151 (1997), 1341-1351.

[86] T.N. Kledal, M.M. Rosenkilde, F. Coulin, G. Simmons, A.H. Johnsen, S. Alouani, C.A. Power, H.R. Luttichau, J. Gerstoft, P.R. Clapham, I. Clark-Lewis, T.N. Wells and T.W. Schwartz, A broad-spectrum chemokine antagonist encoded by Kaposi's sarcoma-associated herpesvirus, Science $\mathbf{2 7 7}$ (1997), 1656-1659.

[87] P.D. Bieniasz, R.A. Fridell, I. Aramori, S.S. Ferguson, M.G. Caron and B.R. Cullen, HIV-1-induced cell fusion is mediated by multiple regions within both the viral envelope and the CCR-5 co-receptor, EMBO J 16 (1997), 2599-2609.

[88] L. Picard, G. Simmons, C.A. Power, A. Meyer, R.A. Weiss and P.R. Clapham, Multiple extracellular domains of CCR-
5 contribute to human immunodeficiency virus type 1 entry and fusion, J Virol 71 (1997), 5003-5011.

[89] T. Dragic, A. Trkola, S.W. Lin, K.A. Nagashima, F. Kajumo, L. Zhao, W.C. Olson, L. Wu, C.R. Mackay, G.P. Allaway, T.P. Sakmar, J.P. Moore and P.J. Maddon, Amino-terminal substitutions in the CCR5 coreceptor impair gp120 binding and human immunodeficiency virus type 1 entry, $J$ Virol $\mathbf{7 2}$ (1998), 279-285

[90] P. Trivedi, D. Horejsh, S.B. Hinds, P.W. Hinds, II, M.S. Wu, M.S. Salvato and C.D. Pauza, Intrarectal transmission of simian immunodeficiency virus in rhesus macaques: selective amplification and host responses to transient or persistent viremia, J Virol 70 (1996), 6876-6883.

[91] T. Zhu, N. Wang, A. Carr, D.S. Nam, R. Moor-Jankowski, D.A. Cooper and D.D. Ho, Genetic characterization of human immunodeficiency virus type 1 in blood and genital secretions: evidence for viral compartmentalization and selection during sexual transmission, J Virol 70 (1996), 3098-3107.

[92] D.S. Callaway, R.M. Ribeiro and M.A. Nowak, Virus phenotype switching and disease progression in HIV-1 infection, Proc Biol Sci 266 (1999), 2523-2530.

[93] M. Cornelissen, G. Mulder-Kampinga, J. Veenstra, F. Zorgdrager, C. Kuiken, S. Hartman, J. Dekker, L. van der Hoek, C. Sol, R. Coutinho and et al., Syncytium-inducing (SI) phenotype suppression at seroconversion after intramuscular inoculation of a non-syncytium-inducing/SI phenotypically mixed human immunodeficiency virus population, $J$ Virol 69 (1995), 1810-1818.

[94] J.L. Lathey, R.D. Pratt and S.A. Spector, Appearance of autologous neutralizing antibody correlates with reduction in virus load and phenotype switch during primary infection with human immunodeficiency virus type 1, J Infect Dis $\mathbf{1 7 5}$ (1997), 231-232.

[95] D.C. Montefiori, R.G. Collman, T.R. Fouts, J.Y. Zhou, M. Bilska, J.A. Hoxie, J.P. Moore and D.P. Bolognesi, Evidence that antibody-mediated neutralization of human immunodeficiency virus type 1 by sera from infected individuals is independent of coreceptor usage, J Virol 72 (1998), 18861893.

[96] A. Trkola, T. Ketas, V.N. Kewalramani, F. Endorf, J.M. Binley, H. Katinger, J. Robinson, D.R. Littman and J.P. Moore, Neutralization sensitivity of human immunodeficiency virus type 1 primary isolates to antibodies and CD4-based reagents is independent of coreceptor usage, J Virol 72 (1998), 18761885.

[97] A. Karlsson, K. Parsmyr, E. Sandstrom, E.M. Fenyo and J. Albert, MT-2 cell tropism as prognostic marker for disease progression in human immunodeficiency virus type 1 infection, J Clin Microbiol 32 (1994), 364-370.

[98] M. Koot, I.P. Keet, A.H. Vos, R.E. de Goede, M.T. Roos, R.A. Coutinho, F. Miedema, P.T. Schellekens and M. Tersmette, Prognostic value of HIV-1 syncytium-inducing phenotype for rate of CD4+ cell depletion and progression to AIDS, Ann Intern Med 118 (1993), 681-688.

[99] M. Tersmette, R.A. Gruters, F. de Wolf, R.E. de Goede, J.M. Lange, P.T. Schellekens, J. Goudsmit, H.G. Huisman and F. Miedema, Evidence for a role of virulent human immunodeficiency virus (HIV) variants in the pathogenesis of acquired immunodeficiency syndrome: studies on sequential HIV isolates, J Virol 63 (1989), 2118-2125.

[100] M.D. Hazenberg, J.W. Stuart, S.A. Otto, J.C. Borleffs, C.A. Boucher, R.J. de Boer, F. Miedema and D. Hamann, T-cell division in human immunodeficiency virus (HIV)-1 infection is mainly due to immune activation: a longitudinal analysis in 
patients before and during highly active antiretroviral therapy (HAART), Blood 95 (2000), 249-255.

[101] C. Casper, L. Naver, P. Clevestig, E. Belfrage, T. Leitner, J. Albert, S. Lindgren, C. Ottenblad, A.B. Bohlin, E.M. Fenyo and A. Ehrnst, Coreceptor change appears after immune deficiency is established in children infected with different HIV-1 subtypes, AIDS Res Hum Retroviruses 18 (2002), 343-352.

[102] J.R. Fiore, A. Bjorndal, K.A. Peipke, M. Di Stefano, G. Angarano, G. Pastore, H. Gaines, E.M. Fenyo and J. Albert, The biological phenotype of HIV-1 is usually retained during and after sexual transmission, Virology 204 (1994), 297-303.

[103] G. Scarlatti, E. Tresoldi, A. Bjorndal, R. Fredriksson, C. Colognesi, H.K. Deng, M.S. Malnati, A. Plebani, A.G. Siccardi, D.R. Littman, E.M. Fenyo and P. Lusso, In vivo evolution of HIV-1 co-receptor usage and sensitivity to chemokinemediated suppression, Nat Med 3 (1997), 1259-1265.

[104] X.F. Yu, Z. Wang, D. Vlahov, R.B. Markham, H. Farzadegan and J.B. Margolick, Infection with dual-tropic human immunodeficiency virus type 1 variants associated with rapid total $\mathrm{T}$ cell decline and disease progression in injection drug users, J Infect Dis 178 (1998), 388-396.

[105] R.I. Connor and D.D. Ho, Human immunodeficiency virus type 1 variants with increased replicative capacity develop during the asymptomatic stage before disease progression, $J$ Virol 68 (1994), 4400-4408.

[106] R.I. Connor, H. Mohri, Y. Cao and D.D. Ho, Increased viral burden and cytopathicity correlate temporally with CD4+ T-lymphocyte decline and clinical progression in human immunodeficiency virus type 1-infected individuals, J Virol 67 (1993), 1772-1777.

[107] R.A. Fouchier, L. Meyaard, M. Brouwer, E. Hovenkamp and H. Schuitemaker, Broader tropism and higher cytopathicity for CD4+ $\mathrm{T}$ cells of a syncytium-inducing compared to a non-syncytium-inducing HIV-1 isolate as a mechanism for accelerated CD4+ T cell decline in vivo, Virology 219 (1996), 87-95.

[108] A.B. van't Wout, L.J. Ran, C.L. Kuiken, N.A. Kootstra, S.T. Pals and H. Schuitemaker, Analysis of the temporal relationship between human immunodeficiency virus type 1 quasispecies in sequential blood samples and various organs obtained at autopsy, J Virol 72 (1998), 488-496.

[109] R. Correa and M.A. Munoz-Fernandez, Viral phenotype affects the thymic production of new T cells in HIV-1-infected children, AIDS 15 (2001), 1959-1963.

[110] M.B. Zaitseva, S. Lee, R.L. Rabin, H.L. Tiffany, J.M. Farber, K.W. Peden, P.M. Murphy and H. Golding, CXCR4 and CCR5 on human thymocytes: biological function and role in HIV-1 infection, J Immunol 161 (1998), 3103-3113.

[111] M.D. Hazenberg, S.A. Otto, D. Hamann, M.T. Roos, H. Schuitemaker, R.J. de Boer and F. Miedema, Depletion of naive CD4 T cells by CXCR4-using HIV-1 variants occurs mainly through increased T-cell death and activation, AIDS 17 (2003), 1419-1424.

[112] R.R. Regoes and S. Bonhoeffer, The HIV coreceptor switch: a population dynamical perspective, Trends Microbiol $\mathbf{1 3}$ (2005), 269-277.

[113] M. Mild, J. Esbjornsson, E.M. Fenyo and P. Medstrand, Frequent intrapatient recombination between human immunodeficiency virus type $1 \mathrm{R} 5$ and X4 envelopes: implications for coreceptor switch, J Virol 81 (2007), 3369-3376.

[114] T. Cilliers, J. Nhlapo, M. Coetzer, D. Orlovic, T. Ketas, W.C. Olson, J.P. Moore, A. Trkola and L. Morris, The CCR5 and CXCR4 coreceptors are both used by human immunodefi- ciency virus type 1 primary isolates from subtype C, J Virol 77 (2003), 4449-4456.

[115] M. Coetzer, T. Cilliers, M. Papathanasopoulos, G. Ramjee, S.A. Karim, C. Williamson and L. Morris, Longitudinal analysis of HIV type 1 subtype C envelope sequences from South Africa, AIDS Res Hum Retroviruses 23 (2007), 316-321.

[116] J. Repits, M. Oberg, J. Esbjornsson, P. Medstrand, A. Karlsson, J. Albert, E.M. Fenyo and M. Jansson, Selection of human immunodeficiency virus type 1 R5 variants with augmented replicative capacity and reduced sensitivity to entry inhibitors during severe immunodeficiency, J Gen Virol $\mathbf{8 6}$ (2005), 2859-2869.

[117] M. Jansson, E. Backstrom, A. Bjorndal, V. Holmberg, P. Rossi, E.M. Fenyo, M. Popovic, J. Albert and H. Wigzell, Coreceptor usage and RANTES sensitivity of nonsyncytium-inducing HIV-1 isolates obtained from patients with AIDS, J Hum Virol 2 (1999), 325-338.

[118] F.A. Koning, D. Kwa, B. Boeser-Nunnink, J. Dekker, J. Vingerhoed, H. Hiemstra and H. Schuitemaker, Decreasing sensitivity to RANTES (regulated on activation, normally $\mathrm{T}$ cell-expressed and -secreted) neutralization of $\mathrm{CC}$ chemokine receptor 5-using, non-syncytium-inducing virus variants in the course of human immunodeficiency virus type 1 infection, J Infect Dis 188 (2003), 864-872.

[119] L. Gray, J. Sterjovski, M. Churchill, P. Ellery, N. Nasr, S.R. Lewin, S.M. Crowe, S.L. Wesselingh, A.L. Cunningham and P.R. Gorry, Uncoupling coreceptor usage of human immunodeficiency virus type 1 (HIV-1) from macrophage tropism reveals biological properties of CCR5-restricted HIV-1 isolates from patients with acquired immunodeficiency syndrome, Virology 337 (2005), 384-398.

[120] R. Liu, W.A. Paxton, S. Choe, D. Ceradini, S.R. Martin, R. Horuk, M.E. MacDonald, H. Stuhlmann, R.A. Koup and N.R. Landau, Homozygous defect in HIV-1 coreceptor accounts for resistance of some multiply-exposed individuals to HIV-1 infection, Cell 86 (1996), 367-377.

[121] J.J. Martinson, N.H. Chapman, D.C. Rees, Y.T. Liu and J.B. Clegg, Global distribution of the CCR5 gene 32-basepair deletion, Nat Genet 16 (1997), 100-103.

[122] S. Rana, G. Besson, D.G. Cook, J. Rucker, R.J. Smyth, Y. Yi, J.D. Turner, H.H. Guo, J.G. Du, S.C. Peiper, E. Lavi, M. Samson, F. Libert, C. Liesnard, G. Vassart, R.W. Doms, M. Parmentier and R.G. Collman, Role of CCR5 in infection of primary macrophages and lymphocytes by macrophagetropic strains of human immunodeficiency virus: resistance to patient-derived and prototype isolates resulting from the delta ccr5 mutation, J Virol 71 (1997), 3219-3227.

[123] M. Dean, M. Carrington, C. Winkler, G.A. Huttley, M.W. Smith, R. Allikmets, J.J. Goedert, S.P. Buchbinder, E. Vittinghoff, E. Gomperts, S. Donfield, D. Vlahov, R. Kaslow, A. Saah, C. Rinaldo, R. Detels and S.J. O'Brien, Genetic restriction of HIV-1 infection and progression to AIDS by a deletion allele of the CKR5 structural gene. Hemophilia Growth and Development Study, Multicenter AIDS Cohort Study, Multicenter Hemophilia Cohort Study, San Francisco City Cohort, ALIVE Study, Science 273 (1996), 1856-1862.

[124] Y. Huang, W.A. Paxton, S.M. Wolinsky, A.U. Neumann, L. Zhang, T. He, S. Kang, D. Ceradini, Z. Jin, K. Yazdanbakhsh, K. Kunstman, D. Erickson, E. Dragon, N.R. Landau, J. Phair, D.D. Ho and R.A. Koup, The role of a mutant CCR5 allele in HIV-1 transmission and disease progression, Nat Med $\mathbf{2}$ (1996), 1240-1243.

[125] S. Philpott, H. Burger, T. Charbonneau, R. Grimson, S.H. Vermund, A. Visosky, S. Nachman, A. Kovacs, P. Tropper, 
H. Frey and B. Weiser, CCR5 genotype and resistance to vertical transmission of HIV-1, J Acquir Immune Defic Syndr 21 (1999), 189-193.

[126] M. Samson, F. Libert, B.J. Doranz, J. Rucker, C. Liesnard, C.M. Farber, S. Saragosti, C. Lapoumeroulie, J. Cognaux, C. Forceille, G. Muyldermans, C. Verhofstede, G. Burtonboy, M. Georges, T. Imai, S. Rana, Y. Yi, R.J. Smyth, R.G. Collman, R.W. Doms, G. Vassart and M. Parmentier, Resistance to HIV-1 infection in caucasian individuals bearing mutant alleles of the CCR-5 chemokine receptor gene, Nature $\mathbf{3 8 2}$ (1996), 722-725.

[127] D.A. Wilkinson, E.A. Operskalski, M.P. Busch, J.W. Mosley and R.A. Koup, A 32-bp deletion within the CCR5 locus protects against transmission of parenterally acquired human immunodeficiency virus but does not affect progression to AIDS-defining illness, J Infect Dis 178 (1998), 1163-1166.

[128] R. Biti, R. Ffrench, J. Young, B. Bennetts, G. Stewart and T. Liang, HIV-1 infection in an individual homozygous for the CCR5 deletion allele, Nat Med 3 (1997), 252-253.

[129] N.L. Michael, J.A. Nelson, V.N. KewalRamani, G. Chang, S.J. O’Brien, J.R. Mascola, B. Volsky, M. Louder, G.C. White, 2nd, D.R. Littman, R. Swanstrom and T.R. O'Brien, Exclusive and persistent use of the entry coreceptor CXCR4 by human immunodeficiency virus type 1 from a subject homozygous for CCR5 delta32, J Virol 72 (1998), 6040-6047.

[130] H.W. Sheppard, C. Celum, N.L. Michael, S. O’Brien, M. Dean, M. Carrington, D. Dondero and S.P. Buchbinder, HIV1 infection in individuals with the CCR5-Delta32/Delta32 genotype: acquisition of syncytium-inducing virus at seroconversion, J Acquir Immune Defic Syndr 29 (2002), 307313.

[131] I. Theodorou, L. Meyer, M. Magierowska, C. Katlama and C. Rouzioux, HIV-1 infection in an individual homozygous for CCR5 delta 32. Seroco Study Group, Lancet 349 (1997), $1219-1220$.

[132] J. Eugen-Olsen, A.K. Iversen, P. Garred, U. Koppelhus, C. Pedersen, T.L. Benfield, A.M. Sorensen, T. Katzenstein, E. Dickmeiss, J. Gerstoft, P. Skinhoj, A. Svejgaard, J.O. Nielsen and B. Hofmann, Heterozygosity for a deletion in the CKR-5 gene leads to prolonged AIDS-free survival and slower CD4 T-cell decline in a cohort of HIV-seropositive individuals, AIDS 11 (1997), 305-310.

[133] N.L. Michael, L.G. Louie, A.L. Rohrbaugh, K.A. Schultz, D.E. Dayhoff, C.E. Wang and H.W. Sheppard, The role of CCR5 and CCR2 polymorphisms in HIV-1 transmission and disease progression, Nat Med 3 (1997), 1160-1162.

[134] P.A. Zimmerman, A. Buckler-White, G. Alkhatib, T. Spalding, J. Kubofcik, C. Combadiere, D. Weissman, O. Cohen, A. Rubbert, G. Lam, M. Vaccarezza, P.E. Kennedy, V. Kumaraswami, J.V. Giorgi, R. Detels, J. Hunter, M. Chopek, E.A. Berger, A.S. Fauci, T.B. Nutman and P.M. Murphy, Inherited resistance to HIV-1 conferred by an inactivating mutation in CC chemokine receptor 5: studies in populations with contrasting clinical phenotypes, defined racial background, and quantified risk, $\mathrm{Mol} \mathrm{Med} 3$ (1997), 23-36.

[135] T.L. Hoffman, R.R. MacGregor, H. Burger, R. Mick, R.W. Doms and R.G. Collman, CCR5 genotypes in sexually active couples discordant for human immunodeficiency virus type 1 infection status, J Infect Dis 176 (1997), 1093-1096.

[136] C.W. Mandl, S.W. Aberle, J.H. Henkel, E. PuchhammerStockl and F.X. Heinz, Possible influence of the mutant CCR5 Allele on vertical transmission of HIV-1, J Med Virol $\mathbf{5 5}$ (1998), 51-55.
[137] P. Garred, Chemokine-receptor polymorphisms: clarity or confusion for HIV-1 prognosis? Lancet 351 (1998), 2-3.

[138] L. Meyer, M. Magierowska, J.B. Hubert, C. Rouzioux, C. Deveau, F. Sanson, P. Debre, J.F. Delfraissy and I. Theodorou, Early protective effect of CCR-5 delta 32 heterozygosity on HIV-1 disease progression: relationship with viral load. The SEROCO Study Group, AIDS 11 (1997), F73-F78.

[139] T.L. Katzenstein, J. Eugen-Olsen, B. Hofmann, T. Benfield, C. Pedersen, A.K. Iversen, A.M. Sorensen, P. Garred, U. Koppelhus, A. Svejgaard and J. Gerstoft, HIV-infected individuals with the CCR delta32/CCR5 genotype have lower HIV RNA levels and higher CD4 cell counts in the early years of the infection than do patients with the wild type. Copenhagen AIDS Cohort Study Group, J Acquir Immune Defic Syndr Hum Retrovirol 16 (1997), 10-14.

[140] R.E. Edelstein, L.A. Arcuino, J.P. Hughes, A.J. Melvin, K.M. Mohan, P.D. King, C.L. McLellan, B.L. Murante, B.P. Kassman and L.M. Frenkel, Risk of mother-to-infant transmission of HIV-1 is not reduced in CCR5/delta32ccr5 heterozygotes, J Acquir Immune Defic Syndr Hum Retrovirol 16 (1997), 243-246.

[141] A. Mangano, F. Prada, A. Roldan, G. Picchio, R. Bologna and L. Sen, Distribution of CCR-5 delta32 allele in Argentinian children at risk of HIV-1 infection: its role in vertical transmission, AIDS 12 (1998), 109-110.

[142] M. Misrahi, J.P. Teglas, N. N'Go, M. Burgard, M.J. Mayaux, C. Rouzioux, J.F. Delfraissy and S. Blanche, CCR5 chemokine receptor variant in HIV-1 mother-to-child transmission and disease progression in children. French Pediatric HIV Infection Study Group, JAMA 279 (1998), 277-280.

[143] C.M. Rousseau, J.J. Just, E.J. Abrams, J. Casabona, Z. Stein and M.C. King, CCR5del32 in perinatal HIV-1 infection, $J$ Acquir Immune Defic Syndr Hum Retrovirol 16 (1997), 239242.

[144] W.T. Shearer, L.A. Kalish and P.A. Zimmerman, CCR5 HIV1 vertical transmission. Women and Infants Transmission Study Group, J Acquir Immune Defic Syndr Hum Retrovirol 17 (1998), 180-181.

[145] M.L. Romiti, C. Colognesi, C. Cancrini, A. Mas, M. Berrino, F. Salvatori, P. Orlandi, M. Jansson, E. Palomba, A. Plebani, J.M. Bertran, M. Hernandez, M. de Martino, A. Amoroso, P.A. Tovo, P. Rossi, T. Espanol and G. Scarlatti, Prognostic value of a CCR5 defective allele in pediatric HIV-1 infection, Mol Med 6 (2000), 28-36.

[146] L. Ometto, M. Zanchetta, M. Mainardi, G.L. De Salvo, M.C. Garcia-Rodriguez, L. Gray, M.L. Newell, L. Chieco-Bianchi and A. De Rossi, Co-receptor usage of HIV-1 primary isolates, viral burden, and CCR5 genotype in mother-to-child HIV-1 transmission, AIDS 14 (2000), 1721-1729.

[147] V. Boyer, C. Desgranges, M.A. Trabaud, E. Fischer and M.D. Kazatchkine, Complement mediates human immunodeficiency virus type 1 infection of a human $\mathrm{T}$ cell line in a CD4- and antibody-independent fashion, J Exp Med 173 (1991), 1151-1158.

[148] J.M. Harouse, R.G. Collman and F. Gonzalez-Scarano, Human immunodeficiency virus type 1 infection of SK-N-MC cells: domains of gp120 involved in entry into a CD4negative, galactosyl ceramide/3' sulfo-galactosyl ceramidepositive cell line, J Virol 69 (1995), 7383-7390.

[149] T. Schneider, R. Ullrich and M. Zeitz, The immunologic aspects of human immunodeficiency virus infection in the gastrointestinal tract, Semin Gastrointest Dis 7 (1996), 1929. 
[150] S. Bhat, R.V. Mettus, E.P. Reddy, K.E. Ugen, V. Srikanthan, W.V. Williams and D.B. Weiner, The galactosyl ceramide/sulfatide receptor binding region of HIV-1 gp120 maps to amino acids 206-275, AIDS Res Hum Retroviruses 9 (1993), 175-181.

[151] J.P. Ioannidis, D.G. Contopoulos-Ioannidis, P.S. Rosenberg, J.J. Goedert, A. De Rossi, T. Espanol, L. Frenkel, M.J. Mayaux, M.L. Newell, S.G. Pahwa, C. Rousseau, G. Scarlatti, S. Sei, L. Sen and T.R. O'Brien, Effects of CCR5-delta32 and CCR2-64I alleles on disease progression of perinatally HIV-1-infected children: an international meta-analysis, AIDS 17 (2003), 1631-1638.

[152] D.H. McDermott, P.A. Zimmerman, F. Guignard, C.A. Kleeberger, S.F. Leitman and P.M. Murphy, CCR5 promoter polymorphism and HIV-1 disease progression. Multicenter AIDS Cohort Study (MACS), Lancet 352 (1998), 866-870.

[153] M.P. Martin, M. Dean, M.W. Smith, C. Winkler, B. Gerrard, N.L. Michael, B. Lee, R.W. Doms, J. Margolick, S. Buchbinder, J.J. Goedert, T.R. O'Brien, M.W. Hilgartner, D. Vlahov, S.J. O'Brien and M. Carrington, Genetic acceleration of AIDS progression by a promoter variant of CCR5, Science 282 (1998), 1907-1911.

[154] C. Quillent, E. Oberlin, J. Braun, D. Rousset, G. GonzalezCanali, P. Metais, L. Montagnier, J.L. Virelizier, F. ArenzanaSeisdedos and A. Beretta, HIV-1-resistance phenotype conferred by combination of two separate inherited mutations of CCR5 gene, Lancet 351 (1998), 14-18.

[155] M.A. Ansari-Lari, X.M. Liu, M.L. Metzker, A.R. Rut and R.A. Gibbs, The extent of genetic variation in the CCR5 gene, Nat Genet 16 (1997), 221-222.

[156] M. Carrington, M. Dean, M.P. Martin and S.J. O'Brien, Genetics of HIV-1 infection: chemokine receptor CCR5 polymorphism and its consequences, Hum Mol Genet 8 (1999), 1939-1945.

[157] O.M. Howard, A.K. Shirakawa, J.A. Turpin, A. Maynard, G.J. Tobin, M. Carrington, J.J. Oppenheim and M. Dean, Naturally occurring CCR5 extracellular and transmembrane domain variants affect HIV-1 Co-receptor and ligand binding function, J Biol Chem 274 (1999), 16228-16234.

[158] M.W. Smith, M. Dean, M. Carrington, C. Winkler, G.A. Huttley, D.A. Lomb, J.J. Goedert, T.R. O'Brien, L.P. Jacobson, R. Kaslow, S. Buchbinder, E. Vittinghoff, D. Vlahov, K. Hoots, M.W. Hilgartner and S.J. O'Brien, Contrasting genetic influence of CCR2 and CCR5 variants on HIV-1 infection and disease progression. Hemophilia Growth and Development Study (HGDS), Multicenter AIDS Cohort Study (MACS), Multicenter Hemophilia Cohort Study (MHCS), San Francisco City Cohort (SFCC), ALIVE Study, Science 277 (1997), 959-965.

[159] A. Mangano, J. Kopka, M. Batalla, R. Bologna and L. Sen, Protective effect of CCR2-64I and not of CCR5-delta32 and SDF1-3'A in pediatric HIV-1 infection, $J$ Acquir Immune Defic Syndr 23 (2000), 52-57.

[160] C. Winkler, W. Modi, M.W. Smith, G.W. Nelson, X. Wu, M. Carrington, M. Dean, T. Honjo, K. Tashiro, D. Yabe, S. Buchbinder, E. Vittinghoff, J.J. Goedert, T.R. O'Brien, L.P. Jacobson, R. Detels, S. Donfield, A. Willoughby, E. Gomperts, D. Vlahov, J. Phair and S.J. O'Brien, Genetic restriction of AIDS pathogenesis by an SDF-1 chemokine gene variant. ALIVE Study, Hemophilia Growth and Development Study (HGDS), Multicenter AIDS Cohort Study (MACS), Multicenter Hemophilia Cohort Study (MHCS), San Francisco City Cohort (SFCC), Science 279 (1998), 389-393.
[161] A. Brambilla, C. Villa, G. Rizzardi, F. Veglia, S. Ghezzi, A. Lazzarin, M. Cusini, S. Muratori, E. Santagostino, A. Gringeri, L.G. Louie, H.W. Sheppard, G. Poli, N.L. Michael, G. Pantaleo and E. Vicenzi, Shorter survival of SDF13'A/3'A homozygotes linked to CD4+ T cell decrease in advanced human immunodeficiency virus type 1 infection, $J$ Infect Dis 182 (2000), 311-315.

162] M. Magierowska, I. Theodorou, P. Debre, F. Sanson, B. Autran, Y. Riviere, D. Charron and D. Costagliola, Combined genotypes of CCR5, CCR2, SDF1, and HLA genes can predict the long-term nonprogressor status in human immunodeficiency virus-1-infected individuals, Blood 93 (1999), 936-941.

[163] S. Mummidi, S.S. Ahuja, E. Gonzalez, S.A. Anderson, E.N. Santiago, K.T. Stephan, F.E. Craig, P. O'Connell, V. Tryon, R.A. Clark, M.J. Dolan and S.K. Ahuja, Genealogy of the CCR5 locus and chemokine system gene variants associated with altered rates of HIV-1 disease progression, Nat Med $\mathbf{4}$ (1998), 786-793.

[164] R.P. van Rij, S. Broersen, J. Goudsmit, R.A. Coutinho and H. Schuitemaker, The role of a stromal cell-derived factor1 chemokine gene variant in the clinical course of HIV-1 infection, AIDS 12 (1998), F85-F90.

[165] G.C. John, C. Rousseau, T. Dong, S. Rowland-Jones, R. Nduati, D. Mbori-Ngacha, T. Rostron, J.K. Kreiss, B.A. Richardson and J. Overbaugh, Maternal SDF1 3'A polymorphism is associated with increased perinatal human immunodeficiency virus type 1 transmission, J Virol 74 (2000), 5736-5739.

[166] S. Sei, A.M. Boler, G.T. Nguyen, S.K. Stewart, Q.E. Yang, M. Edgerly, L.V. Wood, P. Brouwers and D.J. Venzon, Protective effect of CCR 5 delta 32 heterozygosity is restricted by SDF-1 genotype in children with HIV-1 infection, AIDS 15 (2001), 1343-1352.

[167] E. Tresoldi, M.L. Romiti, M. Boniotto, S. Crovella, F. Salvatori, E. Palomba, A. Pastore, C. Cancrini, M. de Martino, A. Plebani, G. Castelli, P. Rossi, P.A. Tovo, A. Amoroso and G. Scarlatti, Prognostic value of the stromal cell-derived factor 1 3'A mutation in pediatric human immunodeficiency virus type 1 infection, J Infect Dis 185 (2002), 696-700.

[168] S. Faure, L. Meyer, D. Costagliola, C. Vaneensberghe, E. Genin, B. Autran, J.F. Delfraissy, D.H. McDermott, P.M. Murphy, P. Debre, I. Theodorou and C. Combadiere, Rapid progression to AIDS in HIV+ individuals with a structural variant of the chemokine receptor CX3CR1, Science $\mathbf{2 8 7}$ (2000), 2274-2277.

[169] K.K. Singh, M.D. Hughes, J. Chen and S.A. Spector, Genetic polymorphisms in CX3CR1 predict HIV-1 disease progression in children independently of CD4+ lymphocyte count and HIV-1 RNA load, J Infect Dis 191 (2005), 1971-1980.

[170] G. Scarlatti, Mother-to-child transmission of HIV-1: advances and controversies of the twentieth centuries, AIDS $\operatorname{Rev} 6$ (2004), 67-78.

[171] M. Cavarelli, I. Karlsson, M. Zanchetta, L. Antonsson, A. Plebani, C. Giaquinto, E.M. Fenyo, A. De Rossi and G. Scarlatti, HIV-1 with multiple CCR5/CXCR4 chimeric receptor use is predictive of immunological failure in infected children, PLoS ONE 3 (2008), e 3292.

[172] F. Salvatori and G. Scarlatti, HIV type 1 chemokine receptor usage in mother-to-child transmission, AIDS Res Hum Retroviruses 17 (2001), 925-935.

[173] D.L. Tuttle, C.R. Coberley, X. Xie, Z.C. Kou, J.W. Sleasman and M.M. Goodenow, Effects of human immunodeficiency virus type 1 infection on CCR5 and CXCR4 coreceptor ex- 
pression on CD4 T lymphocyte subsets in infants and adolescents, AIDS Res Hum Retroviruses 20 (2004), 305-313.

[174] C. Pasquier, C. Cayrou, A. Blancher, C. Tourne-Petheil, A Berrebi, J. Tricoire, J. Puel and J. Izopet, Molecular evidence for mother-to-child transmission of multiple variants by analysis of RNA and DNA sequences of human immunodeficiency virus type 1, J Virol 72 (1998), 8493-8501.

[175] S.M. Wolinsky, C.M. Wike, B.T. Korber, C. Hutto, W.P. Parks, L.L. Rosenblum, K.J. Kunstman, M.R. Furtado and J.L. Munoz, Selective transmission of human immunodeficiency virus type-1 variants from mothers to infants, Science 255 (1992), 1134-1137.

[176] P. Clevestig, I. Maljkovic, C. Casper, E. Carlenor, S. Lindgren, L. Naver, A.B. Bohlin, E.M. Fenyo, T. Leitner and A. Ehrnst, The X4 phenotype of HIV type 1 evolves from R5 in two children of mothers, carrying X4, and is not linked to transmission, AIDS Res Hum Retroviruses 21 (2005), 371378.

[177] C. Ripamonti, T. Leitner, A. Lauren, I. Karlsson, A. Pastore, M. Cavarelli, L. Antonsson, A. Plebani, E.M. Fenyo and G. Scarlatti, Biological and genetic evolution of HIV type 1 in two siblings with different patterns of disease progression, AIDS Res Hum Retroviruses 23 (2007), 1531-1540.
[178] D.R. Kuritzkes, HIV-1 entry inhibitors: an overview, Curr Opin HIV AIDS 4 (2009), 82-87.

[179] J.P. Moore and D.R. Kuritzkes, A piece de resistance: how HIV-1 escapes small molecule CCR5 inhibitors, Curr Opin HIV AIDS 4 (2009), 118-124.

[180] B.J. Doranz, K. Grovit-Ferbas, M.P. Sharron, S.H. Mao, M.B. Goetz, E.S. Daar, R.W. Doms and W.A. O'Brien, A smallmolecule inhibitor directed against the chemokine receptor CXCR4 prevents its use as an HIV-1 coreceptor, J Exp Med 186 (1997), 1395-1400.

[181] T. Murakami, T. Nakajima, Y. Koyanagi, K. Tachibana, N. Fujii, H. Tamamura, N. Yoshida, M. Waki, A. Matsumoto, O. Yoshie, T. Kishimoto, N. Yamamoto and T. Nagasawa, A small molecule CXCR4 inhibitor that blocks T cell linetropic HIV-1 infection, J Exp Med 186 (1997), 1389-1393.

[182] J.D. Reeves and A.J. Piefer, Emerging drug targets for antiretroviral therapy, Drugs 65 (2005), 1747-1766.

[183] G. Hutter, D. Nowak, M. Mossner, S. Ganepola, A. Mussig, K. Allers, T. Schneider, J. Hofmann, C. Kucherer, O. Blau, I.W. Blau, W.K. Hofmann and E. Thiel, Long-term control of HIV by CCR5 Delta32/Delta32 stem-cell transplantation, N Engl J Med 360 (2009), 692-698. 


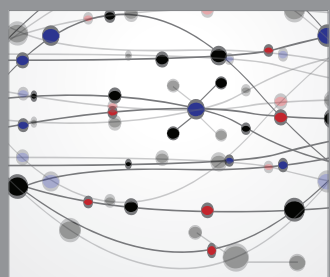

The Scientific World Journal
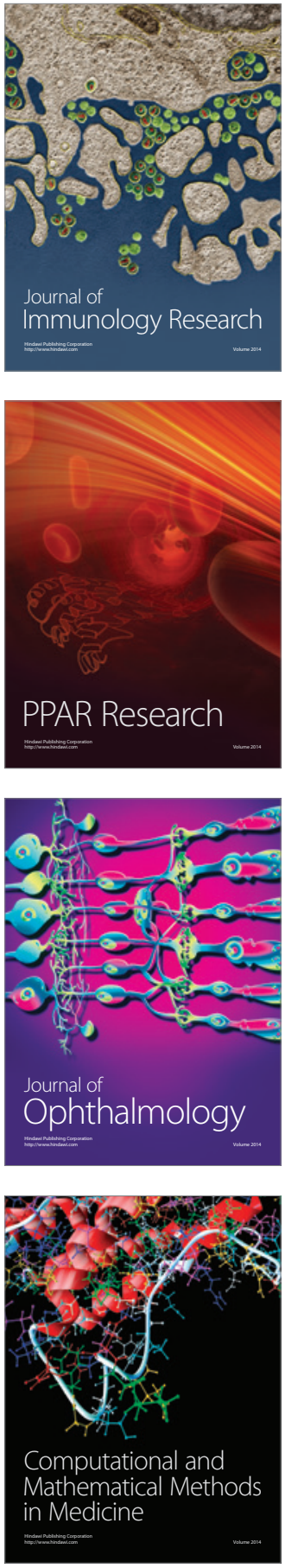

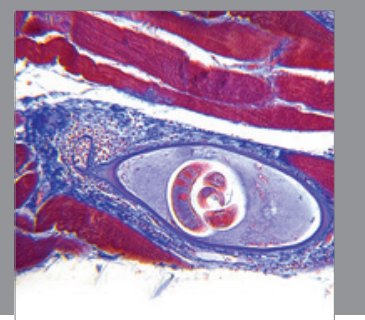

Gastroenterology

Research and Practice
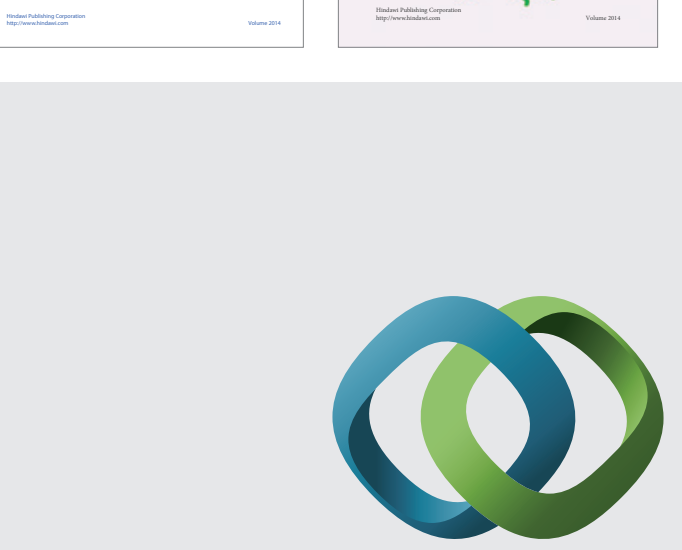

\section{Hindawi}

Submit your manuscripts at

http://www.hindawi.com
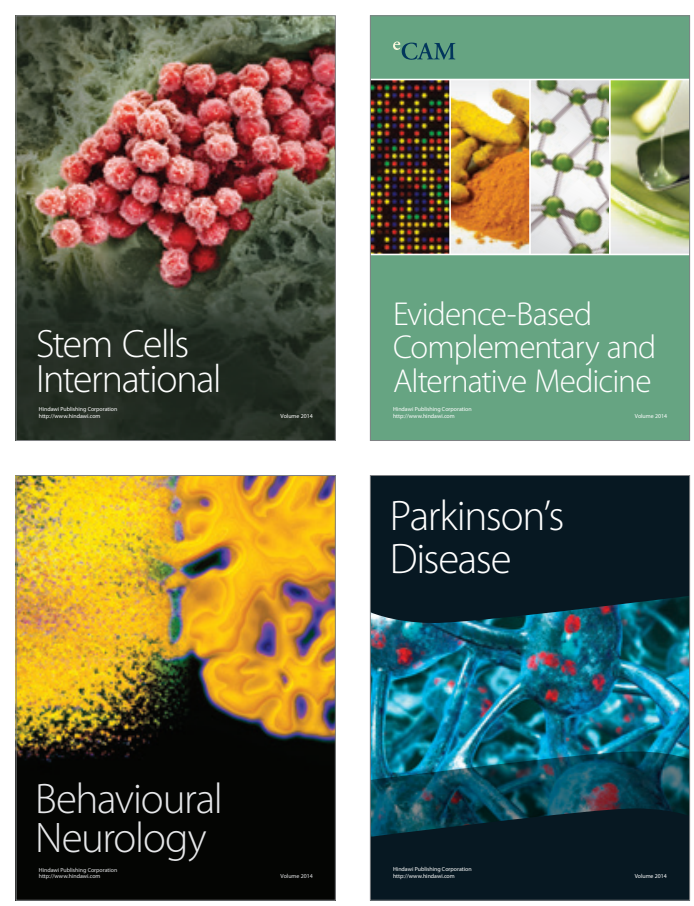

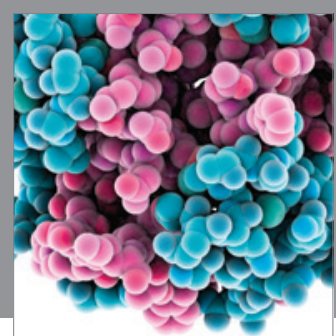

Journal of
Diabetes Research

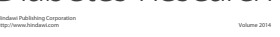

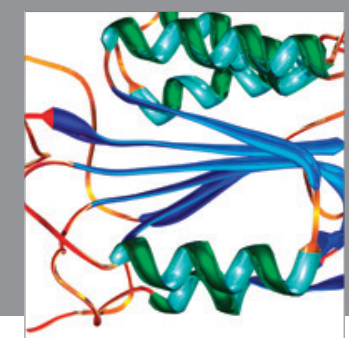

Disease Markers
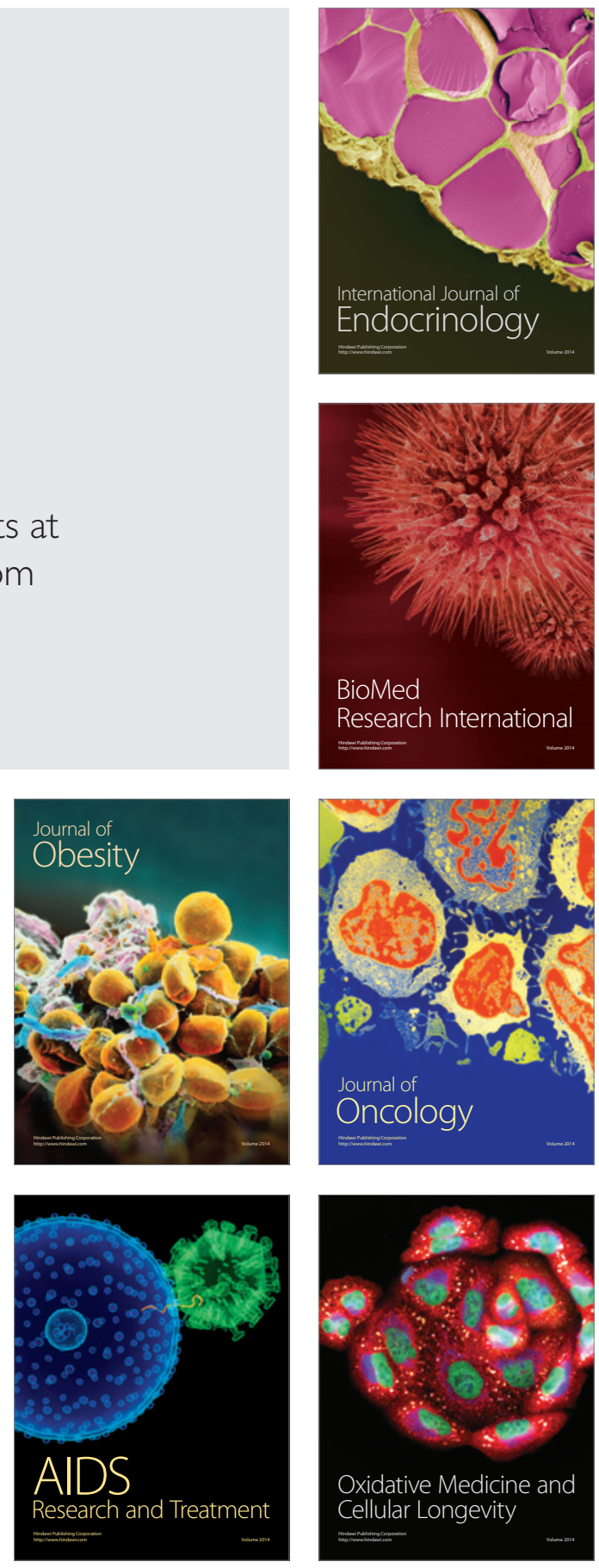